\title{
Long Term Dinoflagellate Bioluminescence, Chlorophyll, and Their Environmental Correlates in Southern California Coastal Waters
}

\author{
David Lapota \\ Space and Naval Warfare Systems Center, Pacific \\ USA
}

\section{Introduction}

While many oceanographic studies have focused on the distribution of bioluminescence in the marine environment (Stukalin 1934, Tarasov 1956, Seliger et al. 1961, Clarke and Kelly 1965, Bityukov 1967, Lapota and Losee 1984, Swift et al. 1985, Lapota et al. 1988, Batchelder and Swift 1989, Lapota et al. 1989, Lapota and Rosenberger 1990, Neilson et al. 1995, Ondercin et al. 1995, Swift et al. 1995), little understanding of the seasonality and sources of planktonic bioluminescence in coastal waters and open ocean has emerged. Some previous studies with respect to annual cycles of bioluminescence were severely limited in duration as well as in the methods used to quantify bioluminescence (Bityukov 1967, Tett 1971). Only a few studies have measured bioluminescence on an extended basis, and these were short in duration, usually less than 2 years with long intervals between sets of measurements (Bityukov 1967, Yentsch and Laird 1968, Tett 1971). Others report data collected at different times of the year (Batchelder and Swift 1989, Batchelder et al. 1992, Buskey 1991) but do not address the seasonality of bioluminescence. Thus the detailed temporal variability of bioluminescence has never been characterized continuously over several years. Lack of such long-term studies leaves unanswered important questions regarding the role of bioluminescence in successional phenomena.

To adequately understand, model, and predict planktonic bioluminescence in any ocean, measurements must be conducted on a continual basis for at least several years in order to evaluate intra- and annual variability and long-term trends. In this study, bioluminescence was measured at two fixed stations on a daily long term basis: one in San Diego Bay (SDB) for 4 years (1992-1996) and the other for 2.5 years (1993-1996) at San Clemente Island (SCI), located $100 \mathrm{~km}$ off the California coast. Additional surface and at-depth bioluminescence data have been collected on a monthly and quarterly basis at both fixed stations and from a research vessel to provide a link between coastal and offshore waters. Additional factors such as seawater temperature, salinity, beam attenuation, and chlorophyll fluorescence were measured. Plankton collections were made weekly in SDB and monthly at SCI. This study provides unique correlated coastal and open ocean data collected on a long-term basis (Figure 1). 


\section{Methods and materials}

\subsection{Bioluminescence measurements}

Two defined excitation moored bathyphotometers (MOORDEX, University of California, Santa Barbara) were used in San Diego Bay (SDB) and at San Clemente Island (SCI). Under control of on-board computers, these measured stimulated bioluminescence, flow rate, and seawater temperature hourly. Every hour, seawater was pumped for $120 \mathrm{sec}$ at 7-8 $\mathrm{L} \mathrm{sec}^{-1}$ for a total volume of approximately $840-960 \mathrm{~L}$ of seawater through a darkened cylindrical $5 \mathrm{l}$ detection chamber approximately $406 \mathrm{~mm}$ long and $127 \mathrm{~mm}$ in diameter (Case et al. 1993, Neilson et al. 1995). Bioluminescence, excited by the chamber spanning input impeller, was measured by a PMT receiving light from 46 fiber optics tips lining the chamber wall and expressed as photons $\mathrm{sec}^{-1} \mathrm{ml}^{-1}$ of seawater.

On monthly transits between SDB and SCI an "on-board" sensor system sampled seawater continuously from $3 \mathrm{~m}$ below the sea surface from a $50 \mathrm{~m}$ research vessel, the $\mathrm{R} / \mathrm{V}$ Acoustic Explorer, measuring bioluminescence, seawater temperature, and salinity (Lapota and Losee 1984, Lapota et al. 1988, 1989). A vertically deployed bathyphotometer capable of measuring bioluminescence, temperature, salinity, beam attenuation, and chlorophyll fluorescence to a depth of $100 \mathrm{~m}$ was used at 4 month intervals (summer, fall, winter, spring) at various stations in the Bight to examine the seasonal changes in the biological and physical structure of the water column (Lapota et at. 1989). Both systems were calibrated with the luminescent bacteria Vibrio harveyii in a Quantalum 2000 siliconphotodiode detector. The detector calibration is traceable to a luminol light standard (Matheson et al. 1984).

\subsection{Plankton and seawater analysis}

Water and plankton samples were collected at 10 stations within the Bight (Figure 1). Monthly transits were made from March 1994 through June 1996 from SCI to SDB to measure surface ( $3 \mathrm{~m}$ depth) bioluminescence and collect plankton and seawater samples to determine $\mathrm{Chl} a$ content. At SDB, weekly plankton and water samples were taken for 4 years while monthly plankton and water samples were collected at SCI for 2.5 years. Because plankton abundance within SDB is usually high, $10 \mathrm{~L}$ water samples were concentrated while 401 samples were filtered for plankton at SCI. Fifteen-liter water samples were collected and filtered from select bathyphotometer depths on the quarterly stations $(10,20$, 30, 40, 50, 70, and $90 \mathrm{~m}$ ). This was accomplished by discharging the bathyphotometer's effluent from its submersible pump through a $130-\mathrm{m}$ long, $2.54 \mathrm{~cm}$ (I.D.) hose into a 15 liter Imhoff settling cone. The bottom of the cone was modified with a valve that allowed water to be filtered into collection cups fitted with $20-\mu \mathrm{m}$ porosity netting. One liter of seawater (unfiltered) was also collected at the each of these depths and frozen in precleaned polycarbonate bottles for later chlorophyll and nutrient analysis. Plankton samples were preserved in a 5\% formalin seawater solution. Bioluminescent dinoflagellates were identified to the species level when possible. Chlorophyll $a$ was extracted from the seawater samples using standard methods (APHA 1981) and measured by fluorescence as an estimate of biomass on a Turner Model 112 fluorometer (Sequoia-Turner Corp., Mountain View, CA, U.S.A.) and reported as $\mu \mathrm{g} \mathrm{L}^{-1}$. 


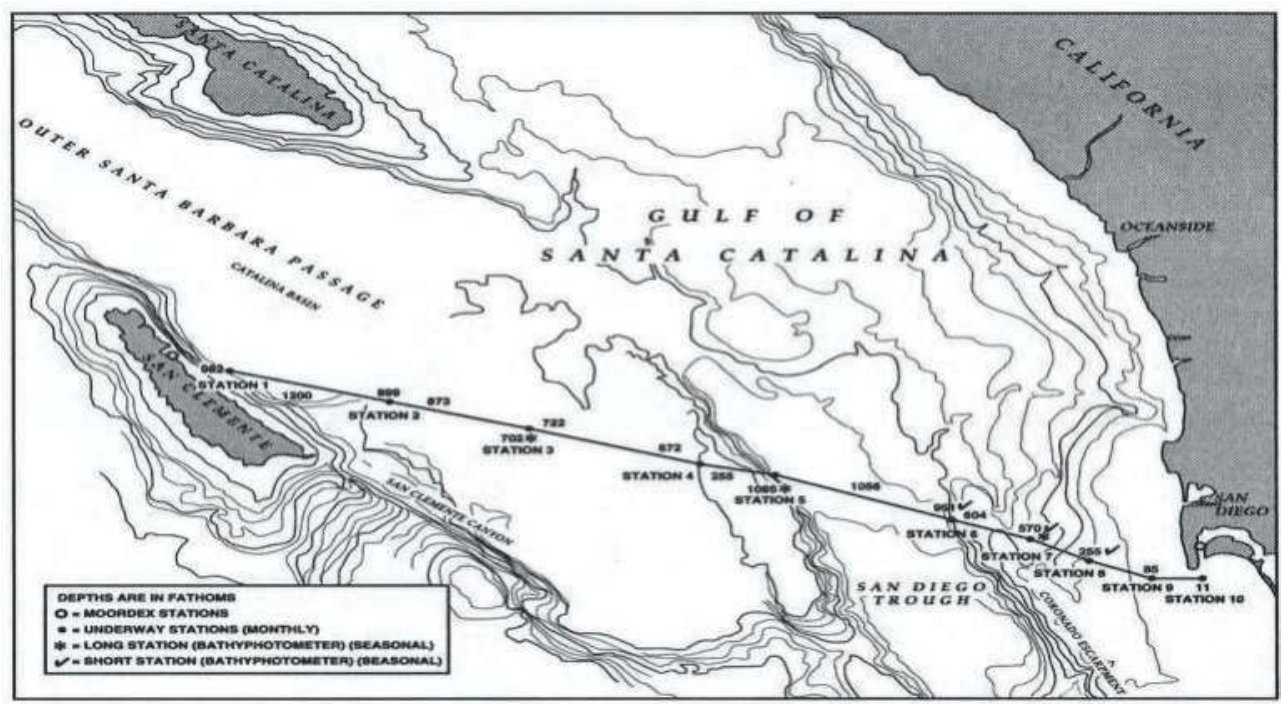

Fig. 1. Bioluminescent study area and cruise track of stations within the Southern California Bight.

\subsection{Upwelling, rainfall, and seawater nutrient data bases}

Upwelling indices (North Pacific Ocean wind-driven transports) were collected from 1992 through 1996. The indices were computed for $33^{\circ} \mathrm{N}$ latitude (Schwing et al. 1996) and represent monthly average surface pressure data in cubic meters per second along each 100 m of coastline (Bakun 1973, Eppley 1986). Monthly rainfall data were acquired from the National Weather Service in San Diego. Nutrient and Chl $a$ data were accessed from archived CALCOFI data (1992-1996) in the Bight and were averaged along CALCOFI lines 90 and 93 which run west from San Diego to the north and south of San Clemente Island (Hayward et al. 1996). Nitrates $\left(\mu \mathrm{m} \mathrm{L}^{-1}\right)$ and Chl $a\left(\mu \mathrm{g} \mathrm{L}^{-1}\right)$ along each of the CALCOFI transit lines (stations 93-26 to 93.45 and 90-28 to 90.53) were averaged from the surface to a depth of 50m for 12 cruises conducted from September 1992 through April 1995. These data were used to calculate correlations with bioluminescence, rainfall, and upwelling at SDB.

\section{Results}

\subsection{Mean monthly bioluminescence}

Hourly bioluminescence data were averaged for each month. Because minimal bioluminescence was measured during daylight hours, mean monthly values were based on data collected from $2100 \mathrm{~h}$ (9:00 P.M.) to $0300 \mathrm{~h}$ (3 A.M.) the following day.

Seasonal changes in bioluminescence were observed in SDB. Maximum bioluminescence (1 x $10^{8}$ photons $\mathrm{s}^{-1} \mathrm{ml}^{-1}$ or greater as a threshold) was measured from March through September for 1993, May through June for 1994, December through May for 1995, and March through April 1996. Minimum bioluminescence (less than $1 \times 10^{8}$ photons s $\mathrm{sl}^{-1} \mathrm{ml}^{-1}$ 
was measured in January through February for 1993, December through February for 199394, November for 1994-95, and January through February for 1996 (Figure 2).

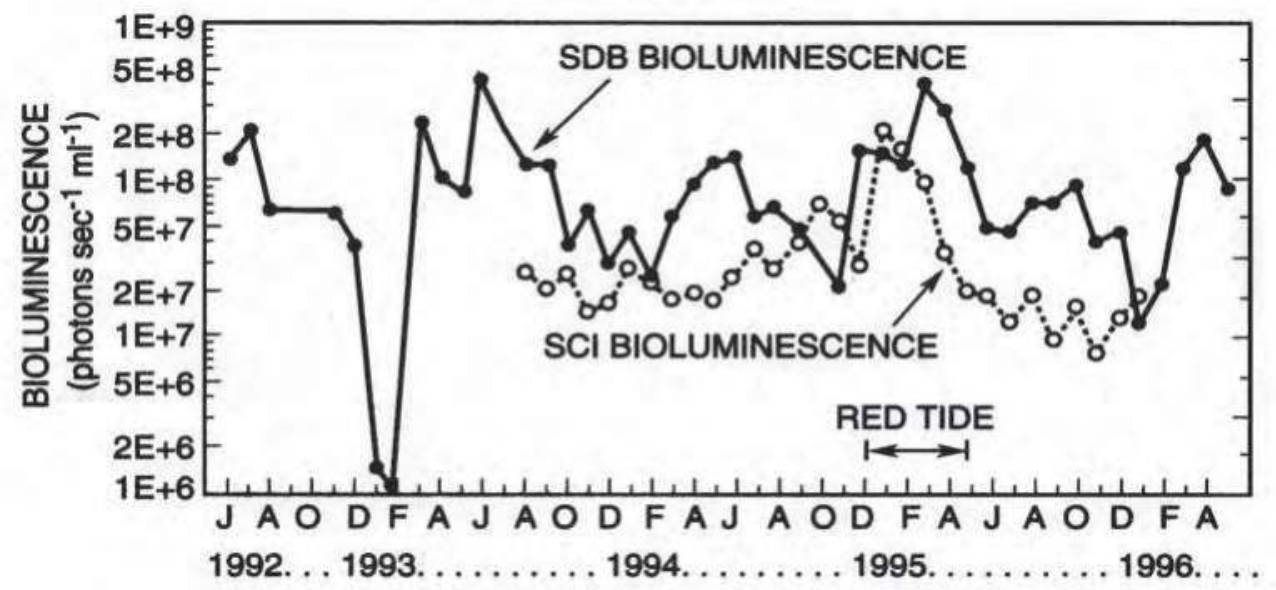

Fig. 2. Mean monthly bioluminescence trends at San Diego Bay and San Clemente Island from 1992-1996.

A red tide of the bioluminescent photosynthetic dinoflagellate, Gonyaulax polyedra, developed in the winter of 1994 along the southern California coast and was correlated with an increase in bioluminescence in SDB in December and later at SCI in January through April 1995 (Figure 2). Noctiluca miliaris appeared in the plankton collections at SCI following this bloom and produced $57 \%$ of the bioluminescence in May 1995. Bioluminescence decreased in SDB during June-July 1995. Mean monthly minimum and maximum bioluminescence in SDB ranged from $1 \times 10^{6}$ (February 1993) - $4.5 \times 10^{8}$ (June 1993) photons $\mathrm{sec}^{-1} \mathrm{ml}^{-1}$. Additionally, during the red tide, bioluminescence averaged 1-2 $\times 10^{8}$ photons $\mathrm{s}^{-1}$ $\mathrm{ml}^{-1}$ from December through April 1995, a factor of 10 above the normal measured winter bioluminescence.

In contrast, mean monthly bioluminescence at SCI varied little from August 1993-February 1996 except during the red tide in January $1995\left(2 \times 10^{8}\right.$ photons s $\left.\mathrm{s}^{-1} \mathrm{ml}^{-1}\right)$ and persisted through April (Figure 2). Mean monthly bioluminescence ranged from $8 \times 10^{6}-3 \times 10^{7}$ photons $\mathrm{s}^{-1} \mathrm{ml}^{-1}$ at SCI.

\subsection{Bioluminescent plankton - San Diego Bay}

Most bioluminescence in SDB and SCI was emitted by the photosynthetic dinoflagellates G. polyedra, Ceratium fusus, Pyrocystis noctiluca as well as from the heterotrophic dinoflagellate, Noctiluca miliaris, and several species of Protoperidinium. Within SDB, maximum numbers of bioluminescent dinoflagellates (2430 - 17,216 cells $\left.\mathrm{L}^{-1}\right)$ were collected during the springsummer months while minimal numbers $\left(3-2,110\right.$ cells $\left.\mathrm{L}^{-1}\right)$ were usually collected in the winter months for 1992, 1993, and 1995 (Figure 3a). 


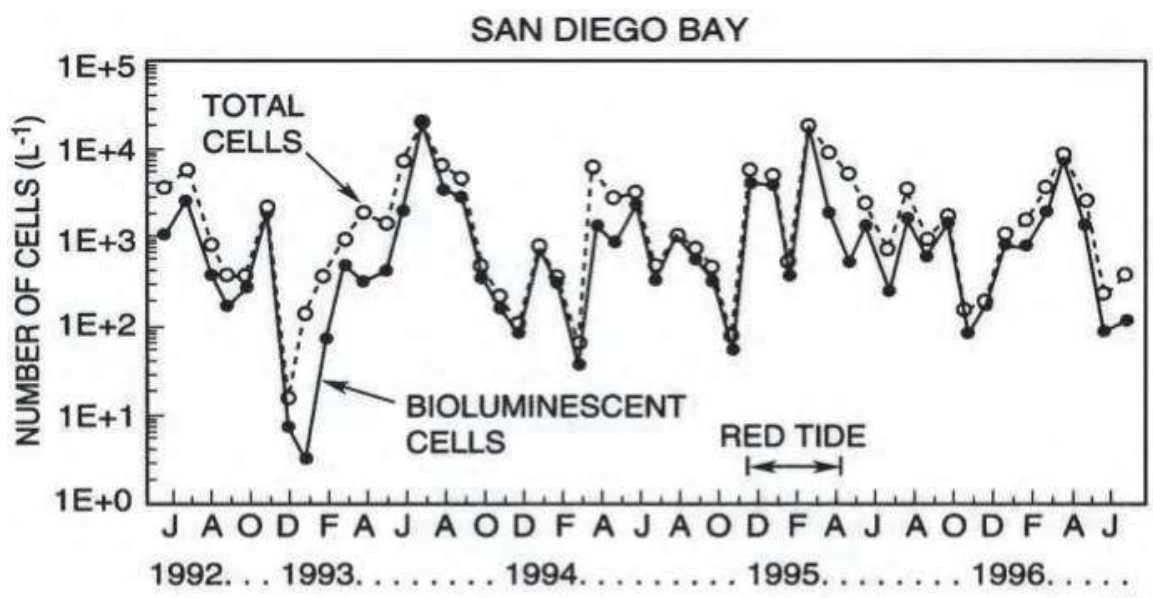

(a)

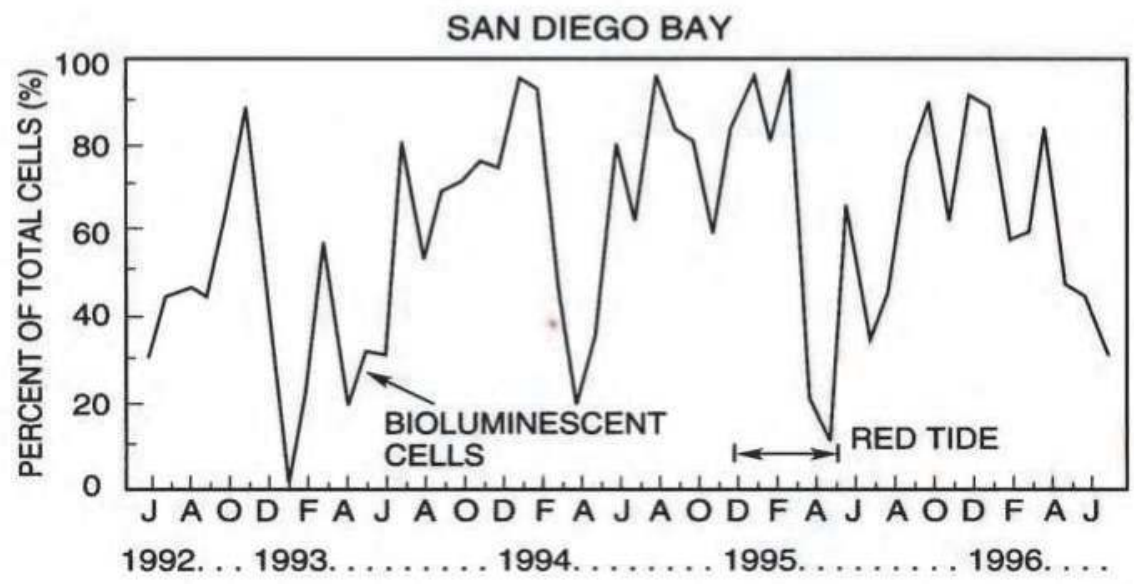

(b)

Fig. 3. (a) Total and bioluminescent dinoflagellates collected monthly in San Diego Bay from 1992-1996. (b) Percent of total dinoflagellate cells which are bioluminescent collected in San Diego Bay from 1992-1996.

In most months bioluminescent dinoflagellates represented a substantial percentage of total dinoflagellates (luminous and non-luminous species) (Figure 3b). Of these, G. polyedra and Protoperidinium spp. were most abundant; found in the winter, spring, and early summer months in SDB (Figure 4). Gonyaulax polyedra contributed more than $80 \%$ of all luminescent cells from early summer 1993 (Figure 3b). Ceratium fusus contributed minimally to the total number of dinoflagellates for the summers of 1993-1994 (Figure 4a). A shift was observed in the dinoflagellate species composition within SDB with G. polyedra becoming the dominant species. There were fewer Protoperidinium spp. and C. fusus at SDB in 1994 (Figure 4). 


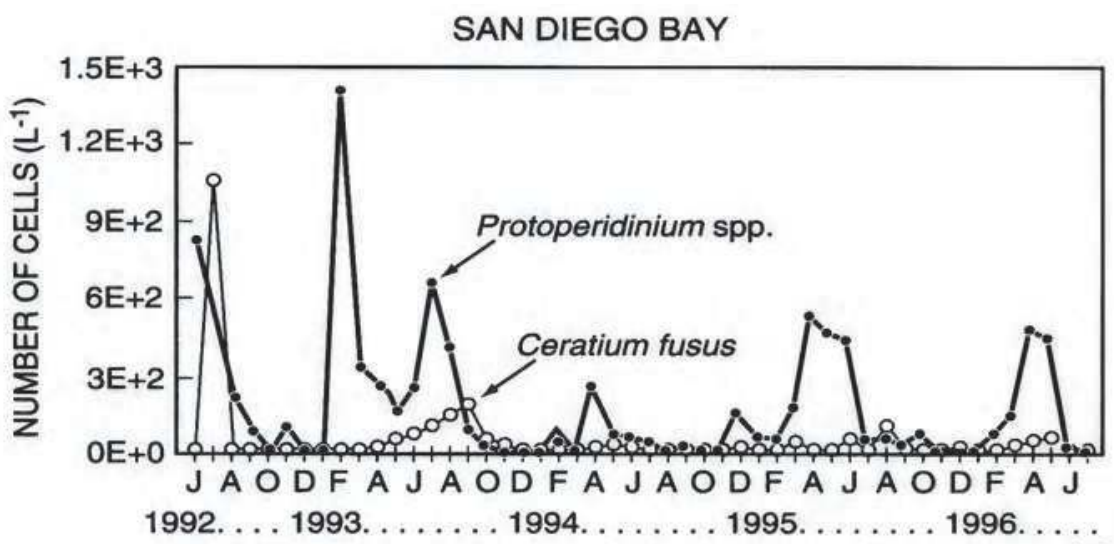

(a)

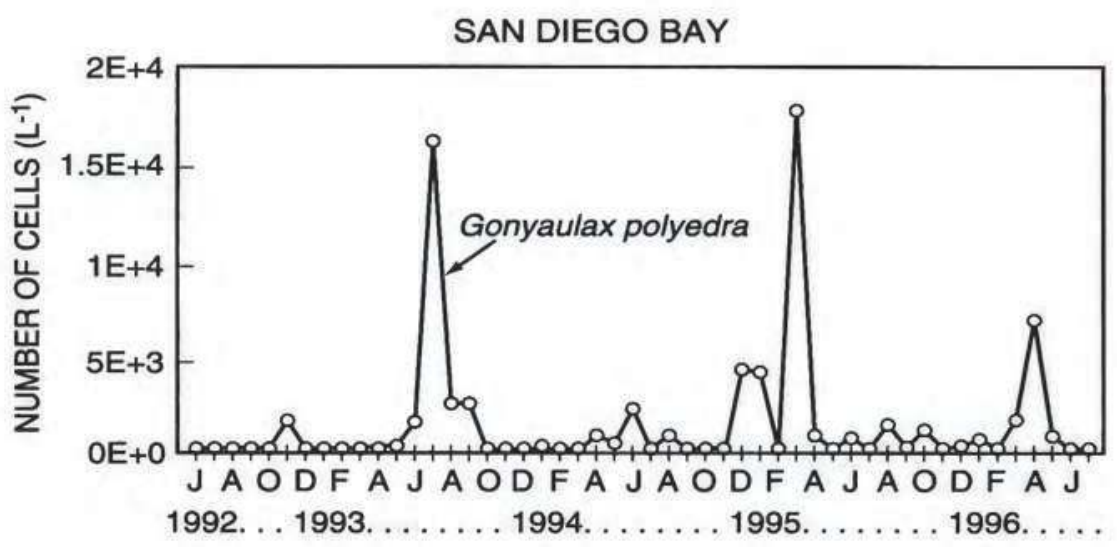

(b)

Fig. 4. (a) The numerical abundance of Ceratium fusus and Protoperidinium spp. each month collected in San Diego Bay from 1992-1996. (b) The numerical abundance of Gonyaulax polyedra each month collected in San Diego Bay from 1992-1996.

A light budget was calculated to estimate the contribution of light produced by the various species of bioluminescent dinoflagellates in SDB. Light output from each was measured with a laboratory photometer system by stirring individual cells for $30 \mathrm{sec}$ (Lapota et al. 1989, Lapota et al. 1992). Mean light output for each species was calculated and then multiplied by the number of cells found in each of the monthly plankton samples. The mean light output values for single cells were: G. polyedra $1 \times 10^{8}$ photons; C. fusus $2 \times 10^{8}$ photons, Protoperidinium spp. $3 \times 10^{9}$ photons, P. noctiluca $1 \times 10^{10}$ photons, and N. miliaris $2 \times 10^{10}$ photons. Photons $\mathrm{L}^{-1}$ for each group were plotted from monthly samples collected in SDB (Figure 5). Bioluminescence from each of the groups (\% of total bioluminescence) was then estimated (Figure 5). Protoperidinium dinoflagellates contributed more than $80 \%$ of the bioluminescence in $41 \%$ of all months ( $\mathrm{n}=51$ months) and more than $50 \%$ of the 
bioluminescence in $73 \%$ of all months. In contrast, G. polyedra contributed more than $80 \%$ of bioluminescence in SDB in only $2 \%$ of all months and more than $50 \%$ of all bioluminescence in $18 \%$ of all months. Gonyaulax polyedra bioluminescence was most pronounced in the fall and winter months. Peaks in C. fusus bioluminescence were most pronounced in late summer and fall, however, the contribution to the light budget was minimal. In 1995 and 1996, G. polyedra dominance in the winter months was followed by an increase in bioluminescence from $N$. miliaris which attained concentrations of 95 cells L-1 in March 1995, 186 cells L-1 in April 1995, and 23 cells L-1 in May 1995. This same trend and similar cell numbers were encountered in the spring months of 1996.

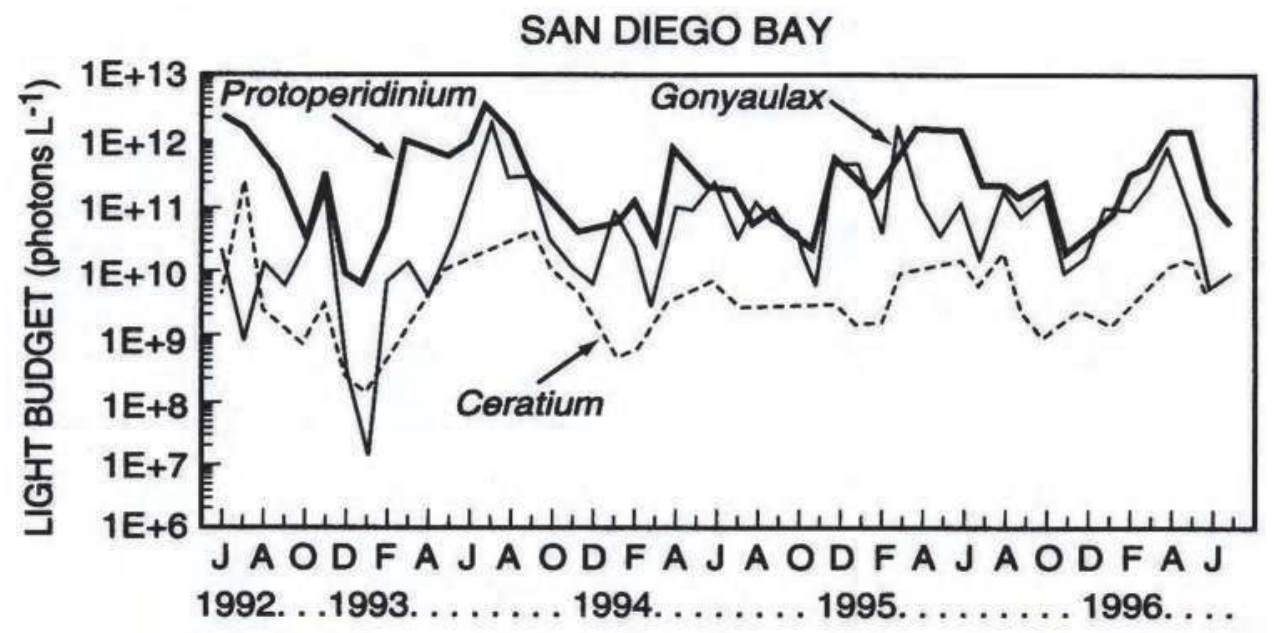

Fig. 5. Bioluminescence produced by each species (photons $\mathrm{L}^{-1}$ ) monthly in San Diego Bay from 1992-1996.

\subsection{Bioluminescent plankton - San Clemente Island}

Numbers of luminescent dinoflagellates were lower at SCI than at SDB, ranging from 3 - 211 cells L-1 of seawater from August 1993 through December 1994 (Figure 6). The principal species were G. polyedra and several species of Protoperidinium. The red tide was first observed in January 1995 and persisted through April 1995. Bioluminescence during this event increased approximately 10 times above former levels for both SDB and SCI, although this difference was measured at SDB one month earlier than SCI (Figure 2). Total dinoflagellates and bioluminescent dinoflagellates increased to 16,727 cells $\mathrm{L}^{-1}$ and 15,939 cells $\mathrm{L}^{-1}$, respectively at SCI in January 1995 (Figure 7a). Cell numbers remained high through April 1995. Gonyaulax polyedra was the predominant red tide bioluminescent dinoflagellate, however several species of Protoperidinium increased to numbers as high as 674 cells L-1 in February 1995 (Figure 7a). At SCI, bioluminescent dinoflagellates represented a major percentage of all dinoflagellates collected (Figure $7 \mathrm{~b}$ ). The light budget analysis indicated that the species of Protoperidinium, again, produced most of the bioluminescence, followed by Gonyaulax and Ceratium species (Figures 8a,8b). At SCI, Protoperidinium contributed more than $80 \%$ of all bioluminescence for $60 \%$ of all months ( $n=30$ months) and 
more than $50 \%$ of all bioluminescence for $77 \%$ of all months. In contrast, Gonyaulax contributed $80 \%$ of all bioluminescence for just 1 month (3.3\% of all months) and $50 \%$ of all bioluminescence for only $10 \%$ of the months. During the red tide encountered in the winter and spring of 1995, G. polyedra contributed 59\%, 42\%, 58\%, 48\%, and $27 \%$ of all bioluminescence for the months of January through May 1995, respectively (Figure 8b). As in SDB, N. miliaris appeared ( $\sim 2$ cells $\left.\mathrm{L}^{-1}\right)$ following the bloom of $G$. polyedra and produced $57 \%$ of the bioluminescence in May 1995 (Figure 8b). The open ocean bioluminescent dinoflagellate, Pyrocystis noctiluca, was also found in monthly collections. Protoperidinium spp.were present in greater numbers in the spring and summer months; while G. polyedra became more prevalent in the fall and winter months.

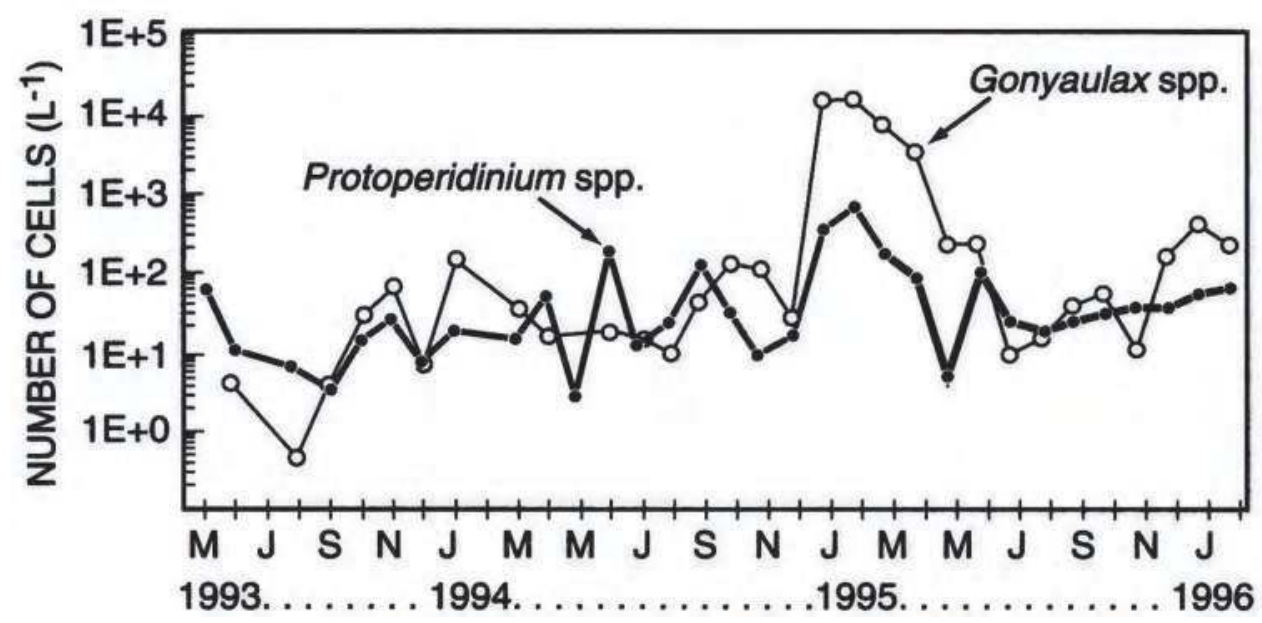

Fig. 6. The abundance of Protoperidinium spp. and Gonyaulax spp. monthly at San Clemente Island from 1993-1996.

The light budget analysis (photons $\mathrm{L}^{-1}$ ) at SDB and SCI correlated with measured

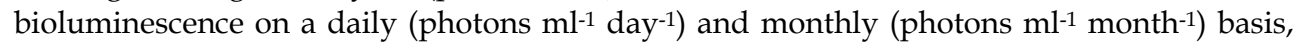
although the light budgets were highly correlated with the later. The light budget analysis reinforces our understanding of which bioluminescent species contributed to measured bioluminescence. SCI had the higher correlations $(\mathrm{r}=0.876 ; \mathrm{p}<0.001)$. This may reflect a more constant plankton assemblage over time in contrast to a more variable bay environment where tidal flow into and out of the bay may cause more variation in the populations sampled (Figure 8)

The change in dinoflagellate species composition between summer and fall is well shown in the monthly transits where surface (3-m depth) plankton samples were collected at 10 stations each month from July through October 1994 (Figure 9). We observed a gradual shift in the ratio of Protoperidinium spp. to G. polyedra between September and October (Figure 9). This trend was also observed in bathyphotometer profiles $(0-90 \mathrm{~m})$ for the July and November 1994 stations across the Bight (Figure 10), with G. polyedra in both instances dominating in the winter months. 


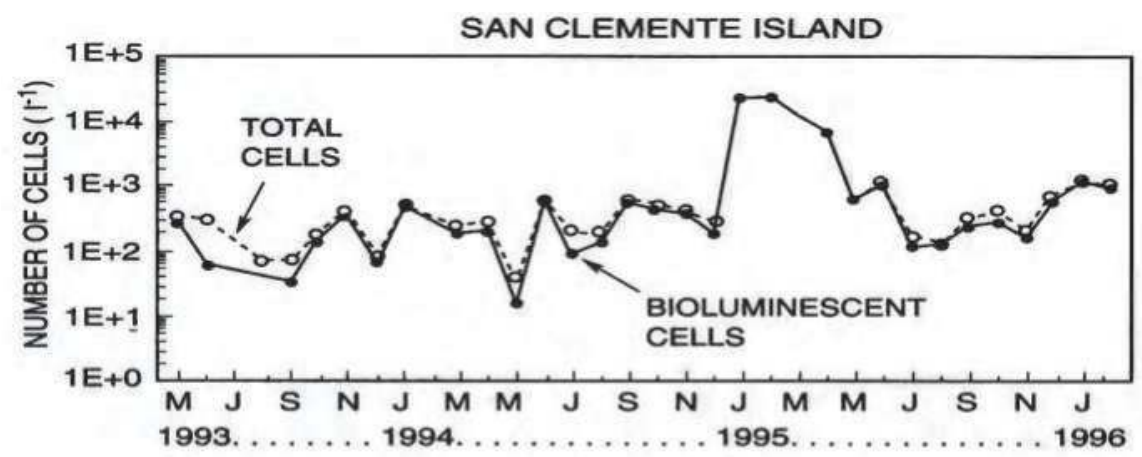

(a)

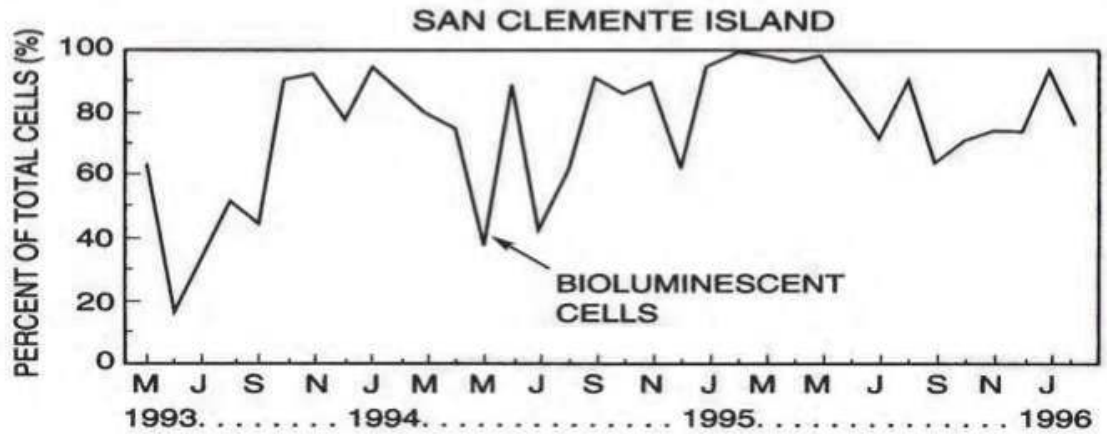

(b)

Fig. 7. (a) Total and bioluminescent dinoflagellate cells collected monthly at San Clemente Island from 1993-1996. (b) Percent of total dinoflagellate cells that are bioluminescent monthly at San Clemente Island from 1993-1996.

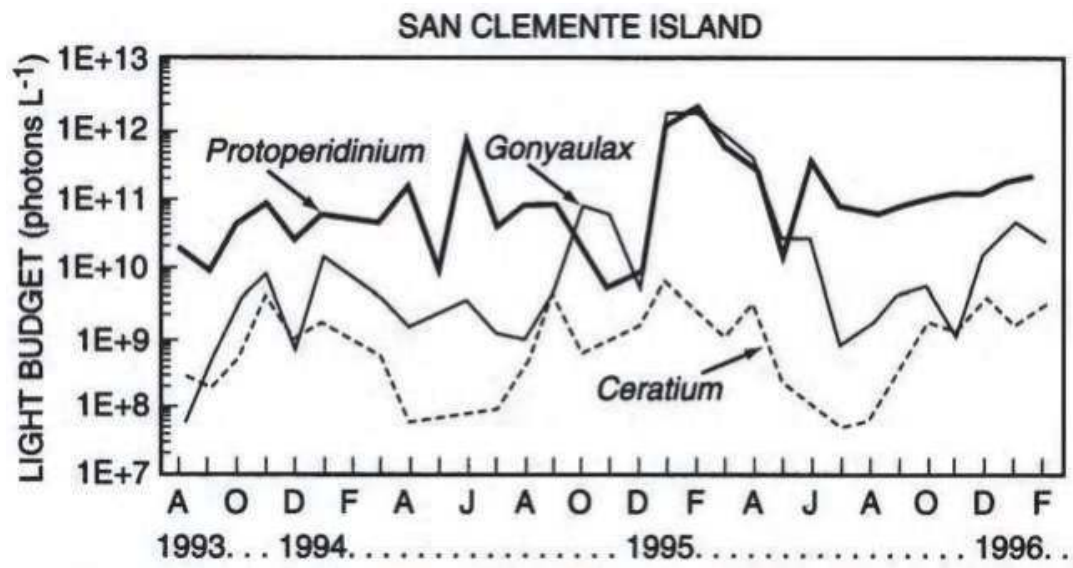

Fig. 8. Bioluminescence produced by each species (photons $\mathrm{L}^{-1}$ ) monthly at San Clemente Island from 1993-1996. 

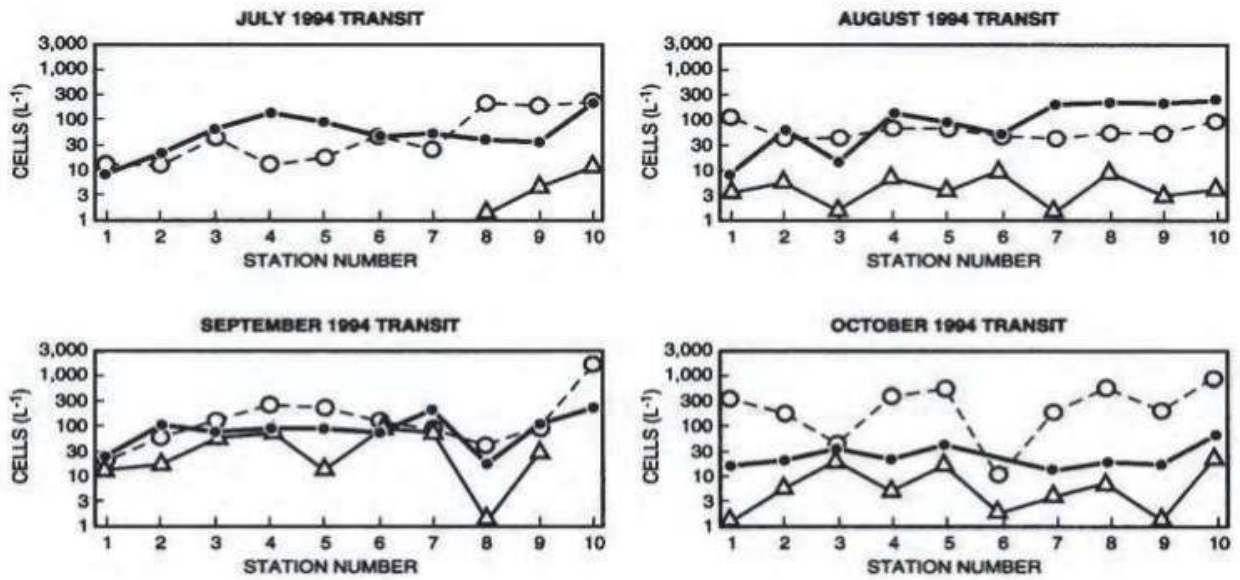

$$
\begin{aligned}
& \text { LEGEND } \\
& -\bullet-\text { Protopendilinium spp. } \\
& -0-\text { Gonyaulax } \\
& -\triangle \text { - Ceratium }
\end{aligned}
$$

Fig. 9. Dinoflagellate species trends for San Clemente Island to San Diego Bay transits from July 1994 to October 1994.
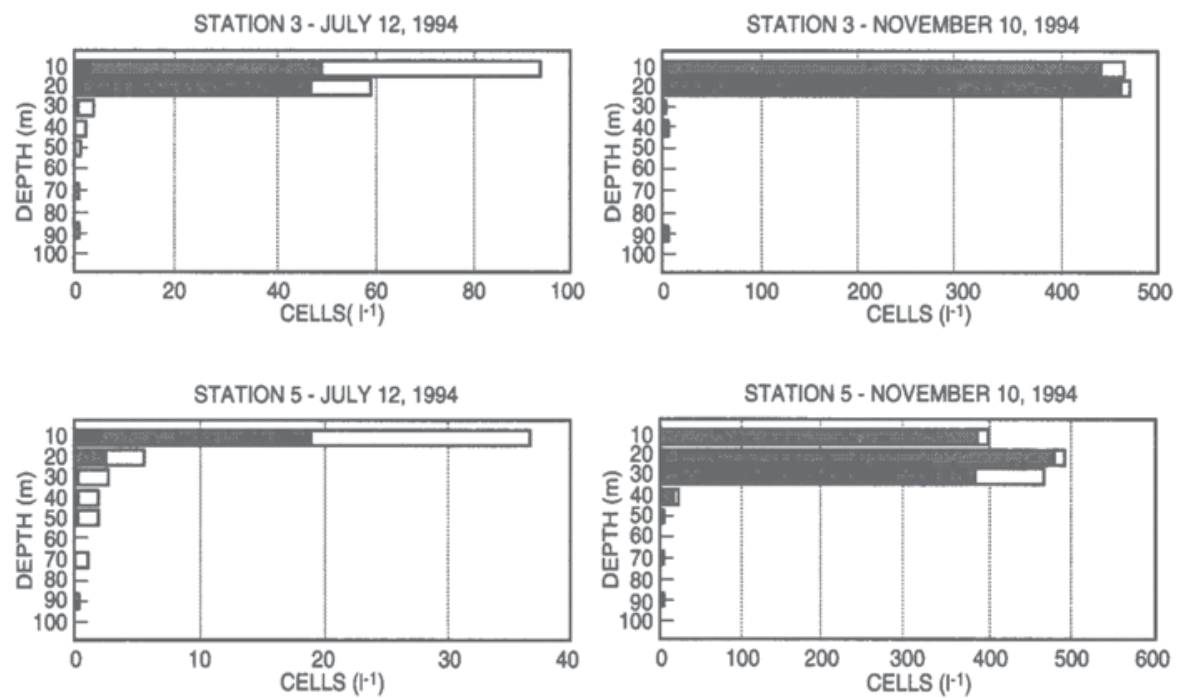

Ceratium fusus

Gonyaulax spp.

Protoperidinium spp.

Fig. 10. Dinoflagellate species trends for San Clemente Island to San Diego Bay transits from July 1994 to October 1994. 


\subsection{Bioluminescence, temperature, rainfall, and chlorophyll relationships}

Seawater temperatures in SDB generally ranged from $14^{\circ} \mathrm{C}$ to $23^{\circ} \mathrm{C}$ (Figure 11) while mean monthly temperatures at SCI ranged from $14.7^{\circ} \mathrm{C}$ to $20^{\circ} \mathrm{C}$ (Figure 12). Correlation coefficients were calculated for both sites. No significant correlations were detected (SDB: $\mathrm{n}=44$ months; $\mathrm{r}=0.131 ; \mathrm{p}>0.10)($ SCI: $\mathrm{n}=30$ months; $\mathrm{r}=-0.241 ; \mathrm{p}>0.10$ ).

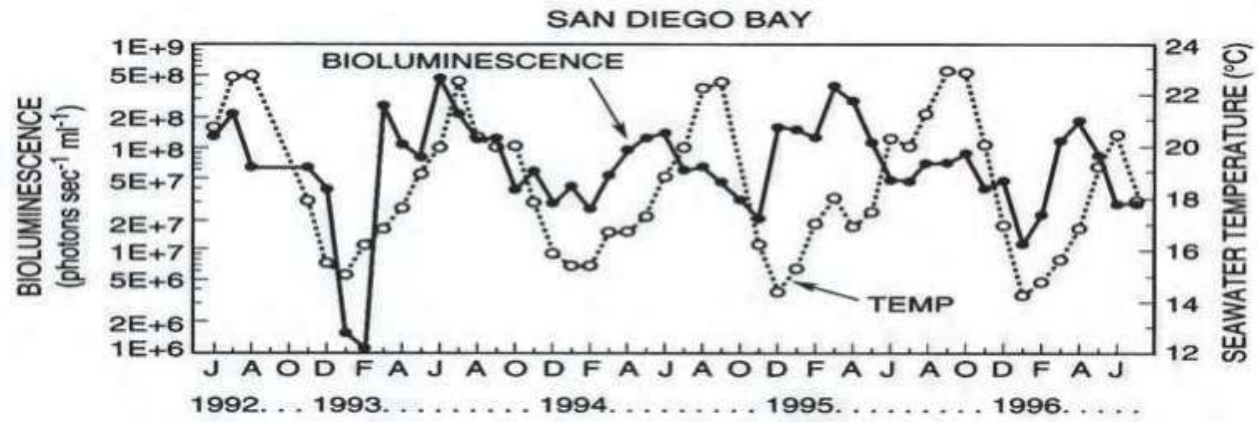

Fig. 11. Mean monthly bioluminescence (photons $\left.\sec ^{-1} \mathrm{ml}^{-1}\right)$ and seawater temperature $\left({ }^{\circ} \mathrm{C}\right)$ at San Diego Bay from 1992-1996.

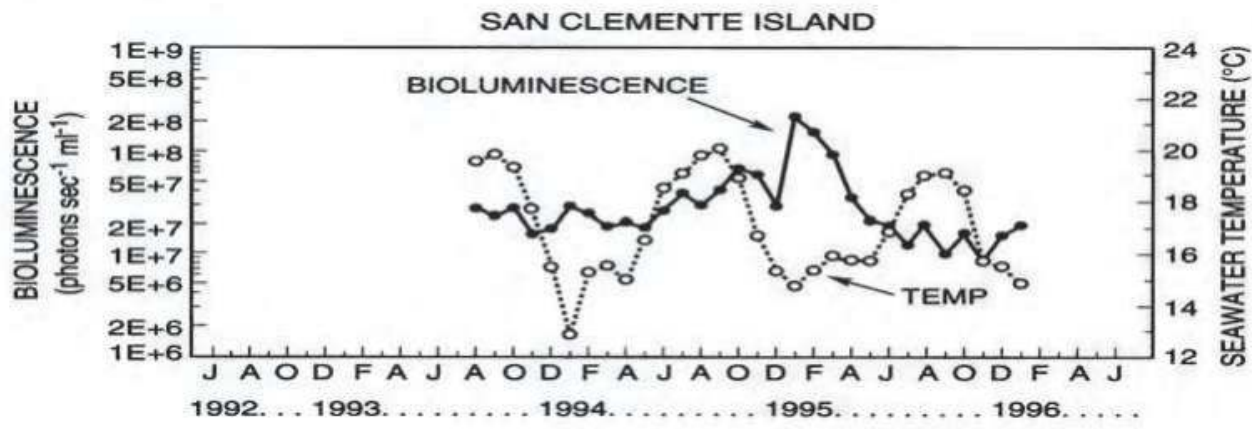

Fig. 12. Mean monthly bioluminescence (photons $\left.\mathrm{sec}^{-1} \mathrm{ml}^{-1}\right)$ and seawater temperature $\left({ }^{\circ} \mathrm{C}\right)$ at San Clemente Island from 1993-1996.

\subsection{Upwelling indices}

Upwelling Indices for $33^{\circ} \mathrm{N}$ latitude were compared to mean monthly bioluminescence for SDB (Schwing et al. 1996). These indices are north Pacific wind-driven transports computed from monthly average surface pressure data in cubic meters of water per second along each 100 meters of coastline (Figure 13). Cold, nutrient rich water containing nitrates and trace metals are brought to the surface as waters are pushed away from the coast. Nitrates are limited in surface waters (Holm-Hansen et al. 1966, Armstrong et al. 1967, Strickland 1968), and are utilized by all phytoplankton for growth (Spencer 1954, Dugdale 1967, MacIsaac and Dugdale 1969). Inspection of the data shows there is a general trend for upwelling and bioluminescence to co-occur during the same months for 1993-1994 (February - November) but not for 1995 and 1996. Correlation coefficients were not significant for both years (1993: 
$\mathrm{n}=8$ months; $\mathrm{r}=0.307 ; \mathrm{p}>0.10),(1994: \mathrm{n}=8$ months; $\mathrm{r}=0.617 ; \mathrm{p}>0.10)$ and all 4 years (1992-1996: $\mathrm{r}=0.111 ; \mathrm{p}>0.10 ; \mathrm{n}=47$ paired monthly points). Bioluminescence actually began to increase in the winter of 1994 before the onset of upwelling (Figure 13) which suggests that some other factor than upwelling may be controlling the onset of maximum bioluminescence.

\subsection{Rainfall effects}

Total rainfall for San Diego County from 1992 through 1996 correlated with SDB bioluminescence. Four years of data (1992-1996) showed that years with the greatest precipitation also had measurably more bioluminescence at SDB (Figure 14). The year 1995 was different than prior years in that rainfall preceded upwelling (Figure 13) with a marked increase in bioluminescence. In addition, years with less monthly rainfall (3-4 inches per month for 1994 and 1996 vs. 8-9 inches per month for 1993 and 1995) exhibited less bioluminescence. Total bioluminescence (photons $\mathrm{ml}^{-1}$ year-1) at San Diego Bay was positively correlated with total rainfall (inches year-1) for all 4 years $(r=0.908 ; n=4$;

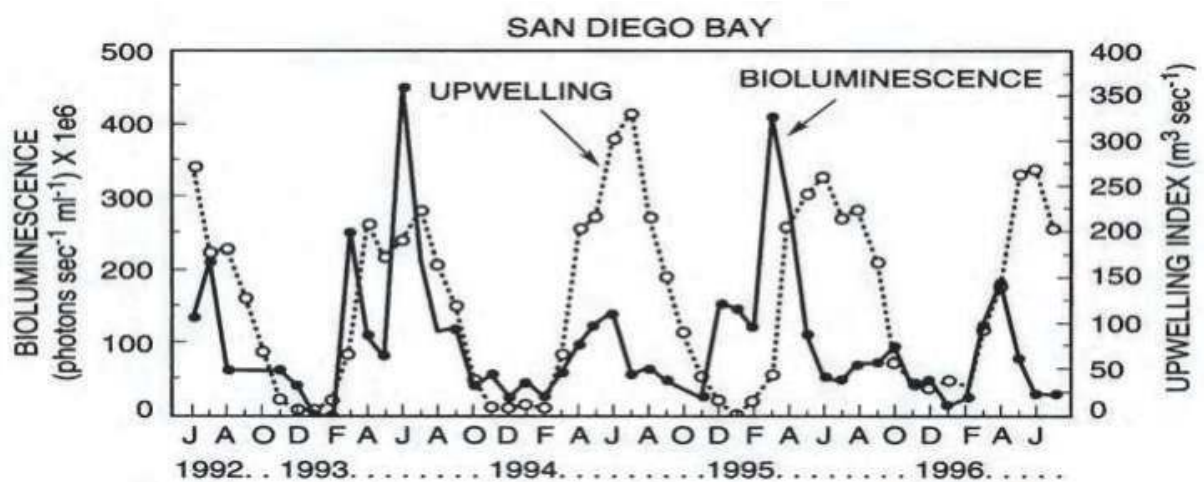

Fig. 13. Mean monthly bioluminescence (photons $\left.\sec ^{-1} \mathrm{ml}-1\right)$ and upwelling index $\left(\mathrm{m}^{3} \mathrm{sec}^{-1}\right)$ for San Diego Bay from 1992-1996.

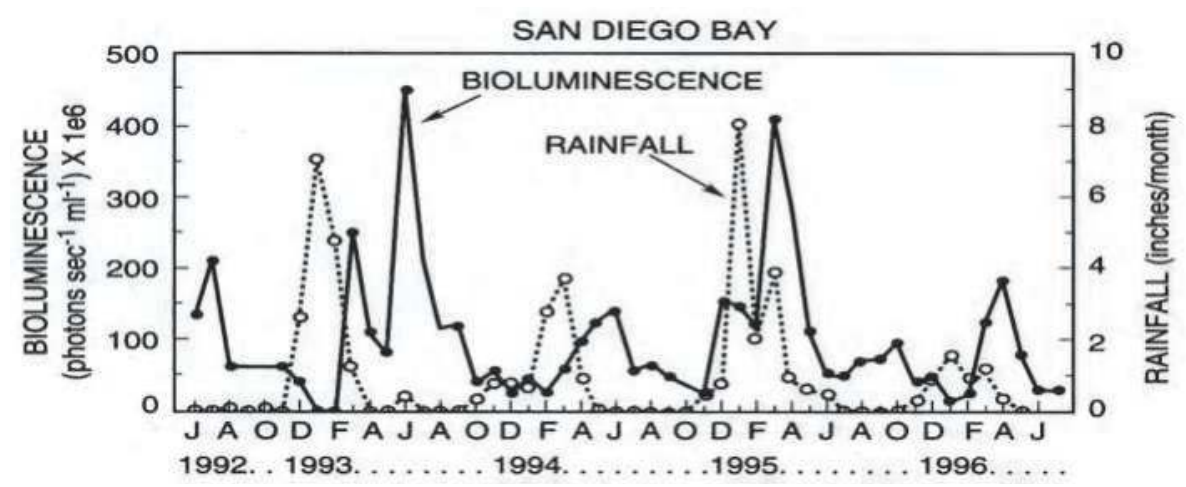

Fig. 14. Mean monthly bioluminescence (photons $\mathrm{sec}^{-1} \mathrm{ml}^{-1}$ ) and monthly rainfall (inches month $^{-1}$ ) for San Diego Bay from 1992-1996. 
$\mathrm{p}<0.05$ ) (Figure 15). Total bioluminescence at SDB was approximately $41 \%$ more in $1992-$ 1993 than in 1993-1994 while 1994-1995 was approximately 66\% and 82\% greater than in 1993-1994 and 1995-1996, respectively (Figure 16). Bioluminescence at SCI was also 287\% greater in 1994-1995 than in 1993-1994. These data suggest that the development of bioluminescence were favored by the consequences of rainfall such as storm runoff nutrients from soil. During the period of 1992 through 1996, of the 77 rain events within San Diego County, 51 events or $66 \%$ of all rain events with $>0.1$ inch of rainfall were associated with a $50 \%$ increase in bioluminescence within three days of the start of rainfall at SDB. Past monitoring programs in San Diego County have shown that storm runoff entering coastal and bay waters during the winter and spring months contains high levels of nitrates and phosphates as well as other nutrients and metals (City of San Diego Stormwater Monitoring Program 1994-1995). CALCOFI data sets also show elevated nitrate levels in surface waters off San Diego along transit lines 90 and 93 following peak rainfall periods.

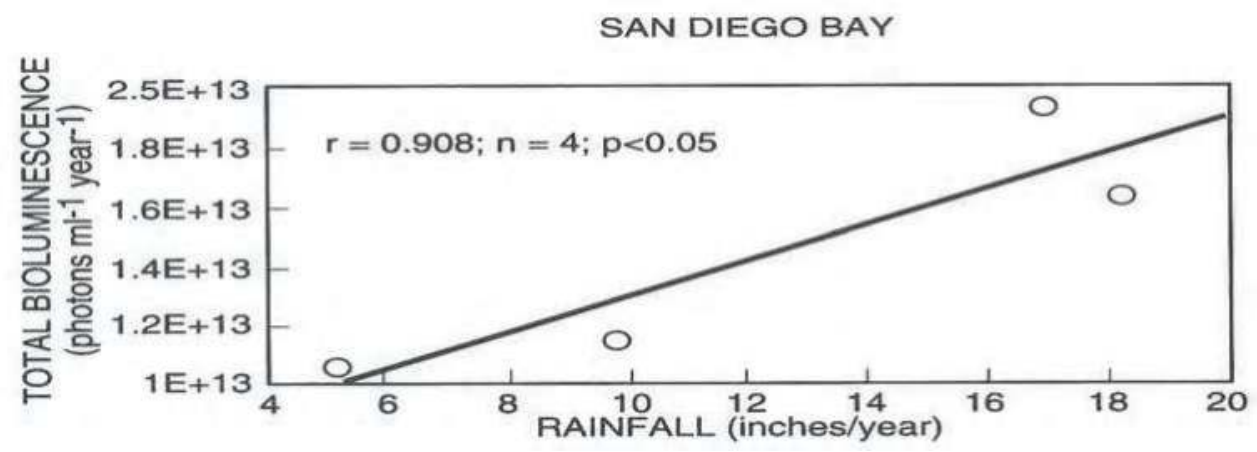

Fig. 15. Correlation of total bioluminescence (photons $\mathrm{ml}^{-1}$ year-1) and total rainfall (inches year $\left.^{-1}\right)$ for San Diego Bay from 1992-1996. ( $r=$ correlation coefficient; $p=$ significance level).

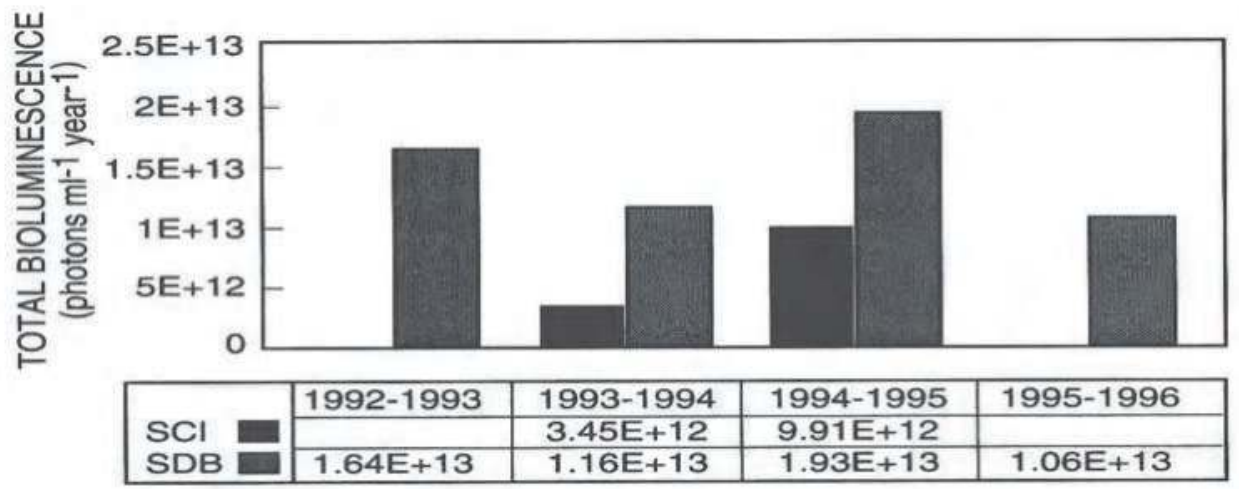

Fig. 16. Total bioluminescence (photons $\mathrm{ml}^{-1}$ year-1) measured at San Diego Bay and San Clemente Island from 1992-1996. 


\subsection{Seasonality of bioluminescence and chlorophyll $a$ at San Clemente Island and San Diego Bay}

Total bioluminescence (photons $\mathrm{ml}^{-1}$ year-1) for each year at SCI and SDB was divided into seasons (Summer, Fall, Winter, and Spring). Total bioluminescence for each month was summed and that subtotal was divided by the entire year's bioluminescence. Seasonal bioluminescence was calculated for SCI (Figure 17a) and SDB (Figure 17b). In 1993-1994, the percent of annual bioluminescence was fairly evenly distributed among all seasons, although the maximum percent of bioluminescence was measured in the winter months at SCI. A winter maximum was again measured the following winter (Figure 17a). For three of the four years at SDB, the maximum percent of annual bioluminescence was measured in the spring. Spring percentages ranged from approximately $30-50 \%$ of all bioluminescence measured for each of the years (Figure 17b).

Seasonal mean Chl a maxima were measured in the spring and winter for 1993-1994 and 1994-1995 at SCI, respectively (Figure 18a). Seasonal mean Chl $a$ maxima were measured in the Spring from 1993-1996 for SDB (Figure 18b). Chl $a$ was usually greater for all seasons at SDB than at SCI.

The seasonal percentages of bioluminescence for SCI and SDB for all years were averaged as were the seasonal means of $\mathrm{Chl} a$ for SCI and SDB for all years. Peak bioluminescence was measured in the winter at SCI and the spring at SDB. Forty-four percent of all bioluminescence measured at SCI was in the winter while only $16.5 \%$ of the year's total was measured in the summer (Figure 19a). Thirty seven percent of all bioluminescence measured at SDB was in the spring while in the fall, only $14 \%$ of the total bioluminescence was measured. Maximum mean $\mathrm{Chl} a$ was also measured in the winter $\left(0.87 \mu \mathrm{g} \mathrm{L}^{-1}\right)$ at SCI as was bioluminescence while maximum mean $\mathrm{Chl} a$ in SDB was measured in the spring $\left(2.39 \mu \mathrm{g} \mathrm{L}^{-1}\right)$ (Figure 19b). San Clemente Island can then be characterized as having winter maxima for bioluminescence and Chl $a$ while San Diego Bay has spring maxima for both.

High levels of chlorophyll at SDB generally occurred either in the spring or summer, although an extended winter - spring peak was measured in January and April-May 1993. At SCI, measured Chl $a$ ranged from a low of $0.04 \mu \mathrm{g} \mathrm{L}^{-1}$ in November 1993 to a high of 1.9 $\mu \mathrm{g} \mathrm{Chl} \mathrm{L}-1$ measured in January 1995 which was probably attributable to the presence of high numbers of Gonyaulax, as well as chain diatoms and pico-plankton. Chlorophyll $a$ levels were still high through June 1995 although decreasing through the remaining months. Simple correlations were calculated between monthly means of Chl $a$ and bioluminescence at SDB and SCI. The correlation between monthly Chl $a$ and bioluminescence at SDB was not significant $(\mathrm{r}=0.277 ; \mathrm{n}=43 ; \mathrm{p}<0.10)$. At $\mathrm{SCI}$, the correlation was highly siginificant when red tide data were included $(\mathrm{r}=0.88 ; \mathrm{n}=26 ; \mathrm{p}<0.001)$. However, when the red tide data were deleted (January - March 1995), the correlation was similar to that at SDB and was not significant $(\mathrm{r}=0.237 ; \mathrm{n}=23 ; \mathrm{p}>0.10)$.

Data from the bathyphotometer stations $(n=26)$ for all six cruises into the Bight (July and November 1994, February, June, November 1995 and March 1996) did not provide a significant correlation of water column bioluminescence with Chl a $(0-90 \mathrm{~m})(\mathrm{r}=0.392$; $\mathrm{p}>0.10$ ) (Figure 20). Further, integrated water column data for all stations from 1994-1996 or station averages also did not display an association between bioluminescence and Chl $a$ (Figure 20). 

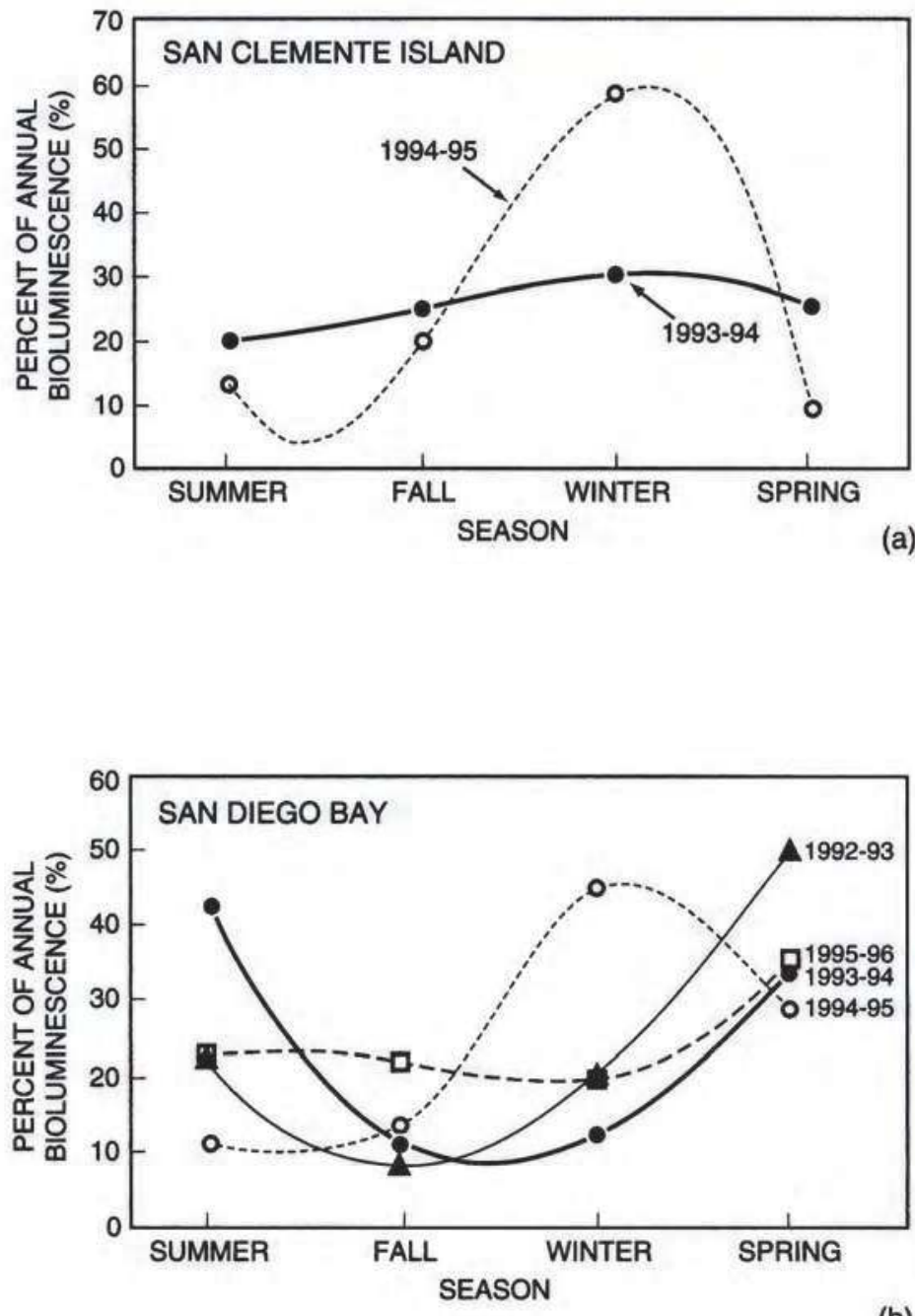

(b)

Fig. 17. (a) Distribution of bioluminescence (\% of annual bioluminescence) by season measured at San Clemente Island from 1983-1995. (b) Distribution of bioluminescence (\% of annual bioluminescence) by season measured in San Diego Bay from 1992-1996. 

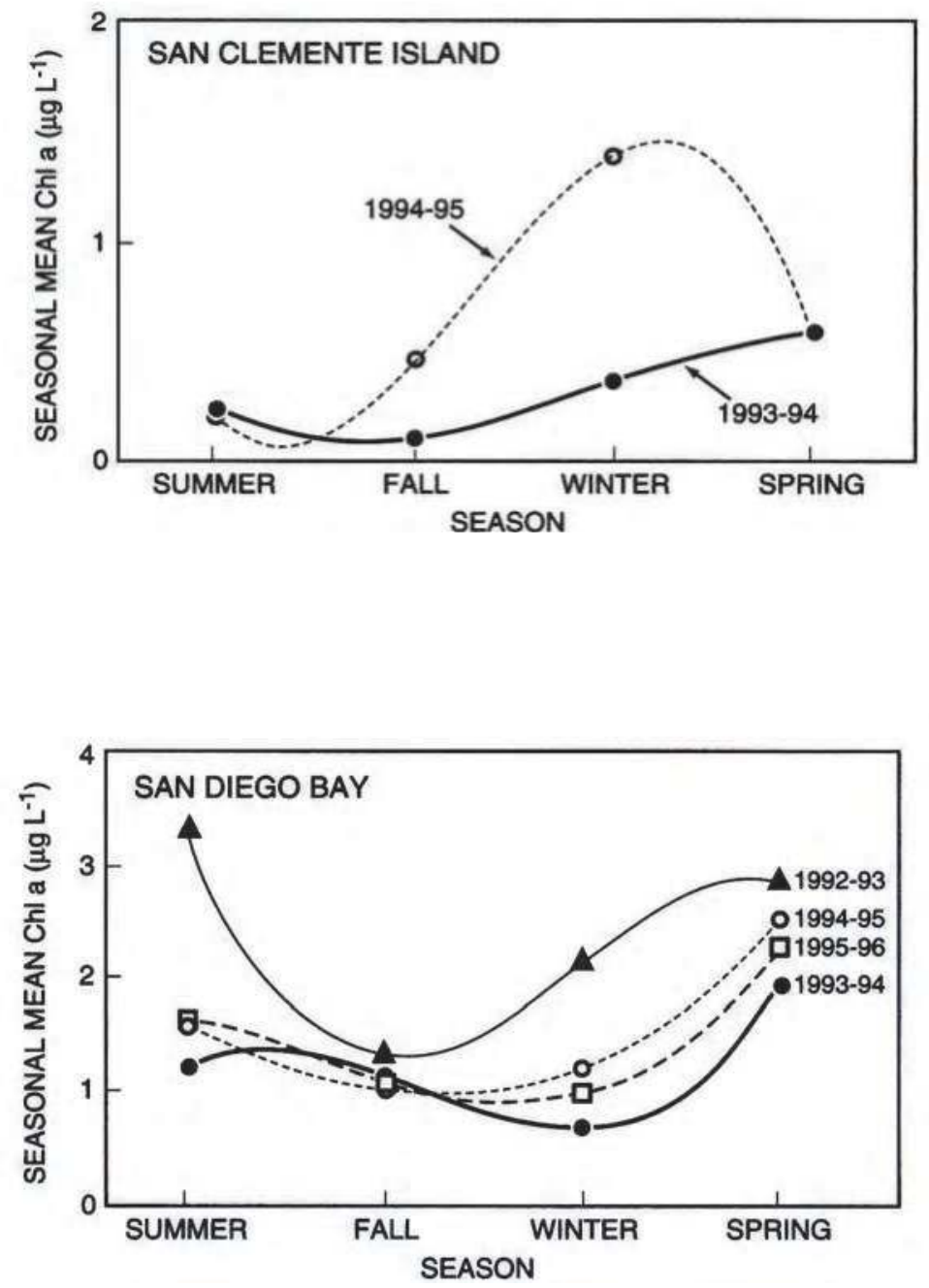

Fig. 18. (a) Seasonal mean Chl $a\left(\mu \mathrm{g} \mathrm{L}^{-1}\right)$ distribution at San Clemente Island from 1993-1995. (b) Seasonal mean Chl $a\left(\mu \mathrm{g} \mathrm{L}^{-1}\right)$ distribution in San Diego Bay from 1992-1996. 

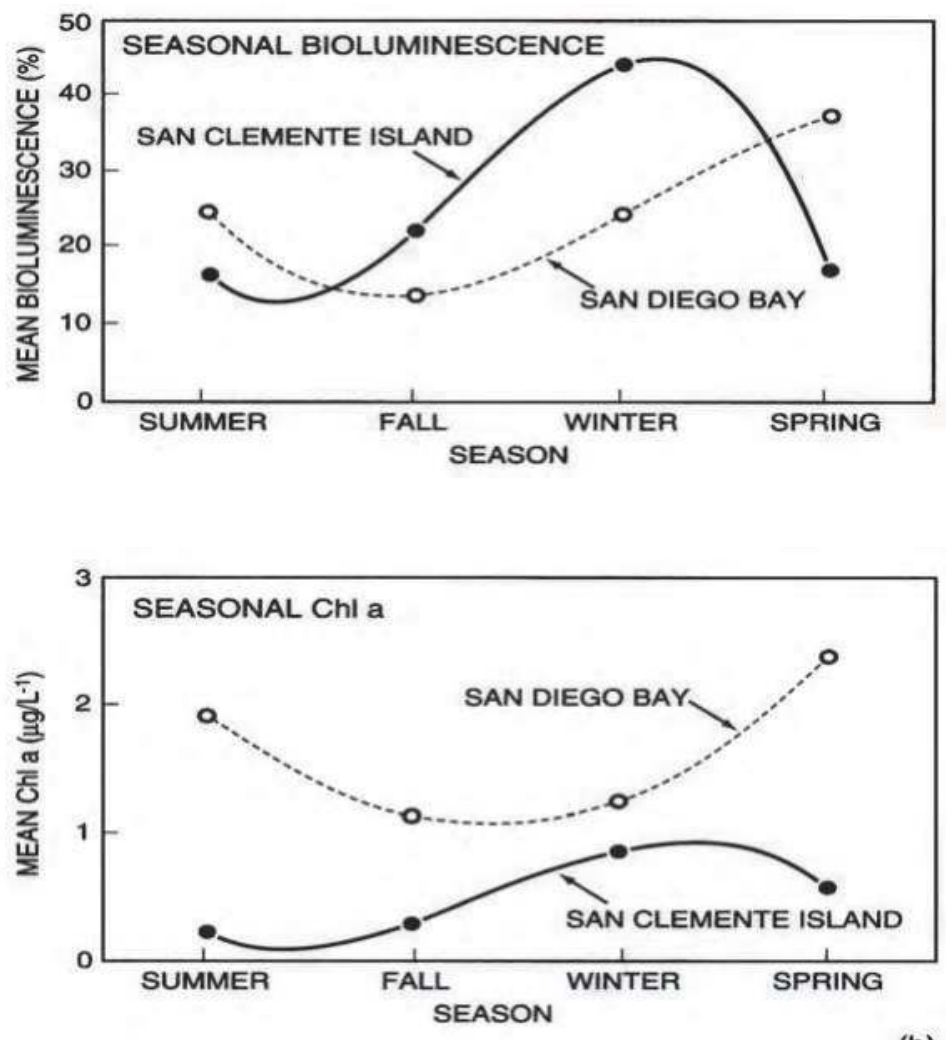

(b)

Fig. 19. (a) Mean seasonal bioluminescence (\% of toal) for all years at San Clemente Island and san Diego Bay. Mean seasonal Chl $a(\mu \mathrm{g} / \mathrm{L})$ distribution for all years at San Clemente Island and San Diego Bay. (b) Mean seasonal Chl $a(\mu \mathrm{g} / \mathrm{L})$ distribution for all years at San Clemente Island and San Diego Bay.

Both the mean integrated water column bioluminescence and Chl $a$ increased during the red tide in February 1995 (range: $6 \times 10^{16}-4 \times 10^{17}$ photons s-1 $\mathrm{m}^{-2}$ and $16-112 \mathrm{mg} \mathrm{Chl} \mathrm{m} \mathrm{m}^{-2}$, respectively) (Figure 20) in comparison to previous measurements conducted in November 1994 (range: 7 x $10^{15}-2 \times 10^{16}$ photons s-1 $\mathrm{m}^{-2}$ and $20-31 \mathrm{mg} \mathrm{Chl} \mathrm{m}^{-2}$, respectively). Mean integrated water column bioluminescence in June 1995 returned to former levels measured in July and November 1994. Station averages of integrated bioluminescence increased as the Southern California mainland was approached. Minimum station averages of integrated bioluminescence were measured at stations 2 and 3, east of SCI in the outer Santa Barbara Passage. Maximum station averages were measured at stations 7, 8 and 9, west of the Coronado Escarpment. Water depths here are the shallowest of all stations measured. Station 7 is located in waters with a depth of 1050 meters while station 9 is located in waters with a depth of 155 meters. Stations 2 and 3 are found in waters with depths of 1660 meters and 1290 meters, respectively. 

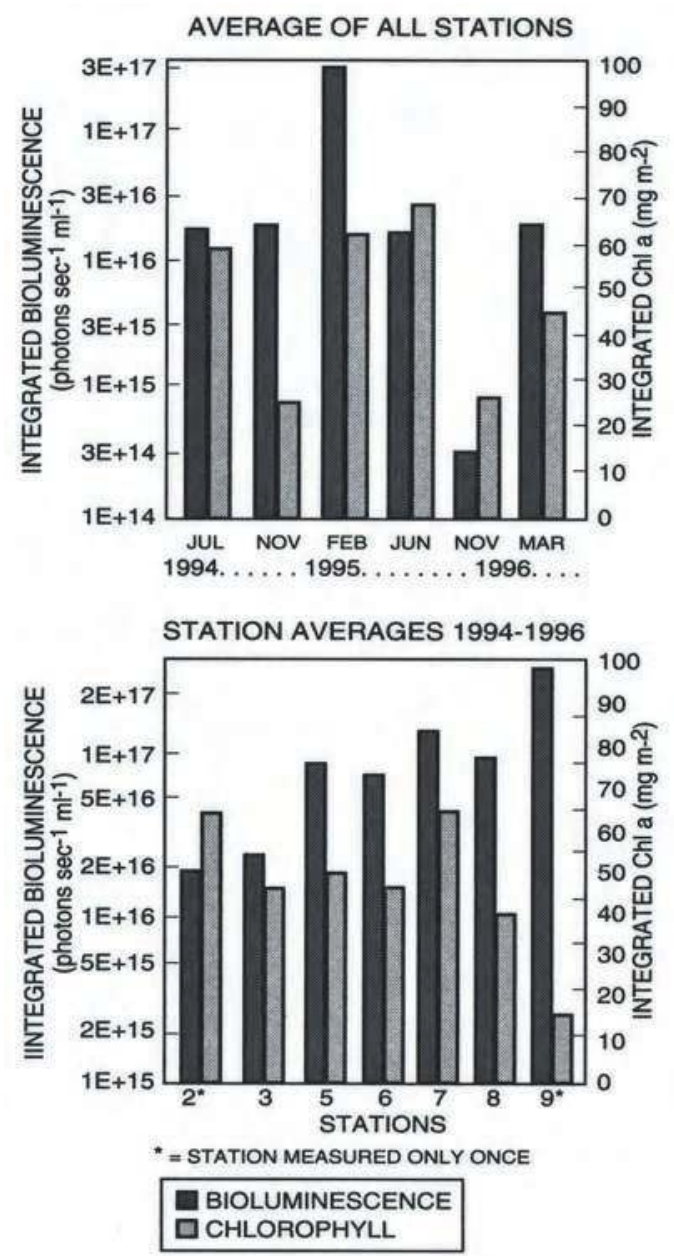

Fig. 20. Integrated bioluminescence (photons sec-1 $\left.\mathrm{m}^{-2}\right)$ and $\mathrm{Chl} a\left(\mathrm{mg} \mathrm{m}^{-2}\right)$ averages of all stations from 1994-1996. Averages of individual stations are also shown.

The vertical structure within the water column with respect to other measured parameters (temperature, percent light transmission, and in vivo Chl fluorescence) changed seasonally (Figure 21). For example, at Station 3 in July (7/12/94), bioluminescence was significantly correlated with in vivo Chl fluorescence $(\mathrm{r}=0.673$; $\mathrm{p}<0.001)$, beam attenuation $(\mathrm{r}=0.747$; $\mathrm{p}<0.001)$, and temperature $(\mathrm{r}=0.892 ; \mathrm{p}<0.001$; Figure 21$)$. Beam attenuation was positively correlated with in vivo $\mathrm{Chl}$ fluorescence $(\mathrm{r}=0.831 ; \mathrm{p}<0.001)$. Maximum bioluminescence and in vivo $\mathrm{Chl}$ fluorescence were measured at the bottom of the mixed layer $(20 \mathrm{~m}$ below the sea surface). The mixed layer deepened in November (11/10/94) as did maximum bioluminescence and Chl fluorescence. The correlation between bioluminescence and chlorophyll fluorescence $(\mathrm{r}=0.483 ; \mathrm{p}<0.001)$ in November was significant as was bioluminescence and beam attenuation $(\mathrm{r}=0.954 ; \mathrm{p}<0.001)$ and bioluminescence with 
temperature $(\mathrm{r}=0.889 ; \mathrm{p}<0.001)$. Bioluminescence and in vivo $\mathrm{Chl}$ fluorescence were not correlated February 12, 1995 at station $3(\mathrm{r}=0.062 ; \mathrm{p}>0.10)$, however, bioluminescence was still significantly correlated with temperature $(r=0.765 ; p<0.001)$. On June 13, 1995, bioluminescence and in vivo $\mathrm{Chl}$ fluorescence were significantly correlated $(\mathrm{r}=0.582 ; \mathrm{p}<$ $0.001)$. Bioluminescence and beam attenuation $(r=0.788 ; p<0.001)$ and bioluminescence and temperature $(\mathrm{r}=0.703 ; \mathrm{p}<0.001)$ were significantly correlated. Beam attenuation was significantly correlated with in vivo Chl fluorescence $(\mathrm{r}=0.942 ; \mathrm{p}<0.001)$. These correlations improved as the mixed layer became shallower in June (Figure 21) in comparison to the deeper mixed layer observed in November 1994 and February 1995 (Figure 21).

\section{Discussion}

The data show that bioluminescence changes seasonally in the Southern California Bight coastal waters with a maximum and minimum signal in the spring and fall in SDB (Figures $2,14,17 b, 19 a)$. A winter maximum and summer minimum in bioluminescence was measured at SCI (Figure 2,17a). In SDB and SCI, we observed a change in the dinoflagellate species composition over a year and its contribution to bioluminescence. We also observed a seasonal change in species composition (summer to winter) at SCI and within the bight (Figures 8a, 9, 10). Chlorophyll $a$ also showed similar seasonal trends with respect to location (Figures 18,19). However, measured monthly means of bioluminescence did not correlate with Chl $a$ either at SDB or SCI. Mean monthly surface seawater temperature did not correlate with mean monthly bioluminescence at either site; that is, maximum bioluminescence did not always correlate with either maximum or minimum seawater temperatures (Figures 11, 12), although minimum bioluminescence was measured during the coolest water temperatures (winter) at SDB in 1994 and 1996. The largest peak in bioluminescence measured at SCI (winter 1995) was associated with the coolest seawater temperatures $\left(14-15^{\circ} \mathrm{C}\right)$ during winter (Figure 12). Coolest water temperatures did not correlate with the upwelling index as maximum indices for $33^{\circ} \mathrm{N}$ latitude, $119^{\circ} \mathrm{W}$ longitude generally occurred in June of each year.

Total bioluminescence (photons $\mathrm{ml}^{-1}$ year-1) was always greater at SDB than at SCI. Total bioluminescence at SDB ranged from $1.06 \times 10^{13}$ to $1.93 \times 10^{13}$ photons $\mathrm{ml}^{-1}$ year-1 (measured from 2100 to $0300 \mathrm{hrs}$ each day) while total bioluminescence measured at SCI was from 3.45 x $10^{12}$ to $9.91 \times 10^{12}$ photons $\mathrm{ml}^{-1}$ year-1. In 1993-1994, 3 times more bioluminescence was measured at SDB than at SCI. These differences lessened to a factor of 2 in 1994-1995 between both sites when a massive bioluminescence red tide was observed to extend south from Santa Barbara, California to Ensenada, Mexico and $100 \mathrm{~km}$ offshore to SCI. At times, monthly differences in total bioluminescence were 8 times greater at SDB than at SCI in Spring 1994 and 1995.

Bioluminescent dinoflagellates, in most instances, comprised most of the dinoflagellates collected at SDB and SCI (Figures 3, 7). In SDB, bioluminescent dinoflagellates made up at least $80 \%$ of all dinoflagellates. Numbers of bioluminescent dinoflagellates dropped noticeably in the winter and spring at SDB $(<30 \%$ of total dinoflagellates) at SDB. Decreases in bioluminescent dinoflagellates were observed at SCI in late spring at SCI. The bioluminescent dinoflagellate assemblage at both SDB and SCI was composed of Ceratium, Gonyaulax, Protoperidinium, and Noctiluca species. Pyrocystis noctiluca was a recurring species 


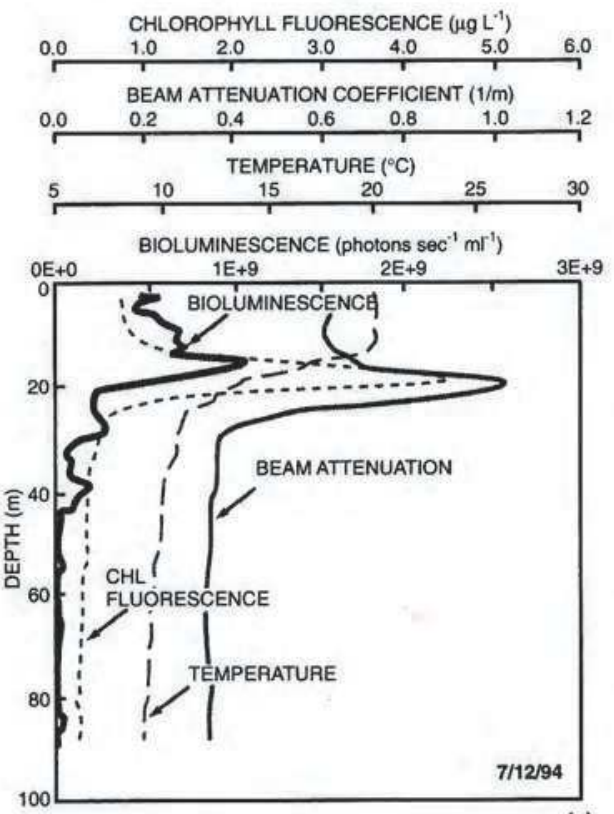

(a)

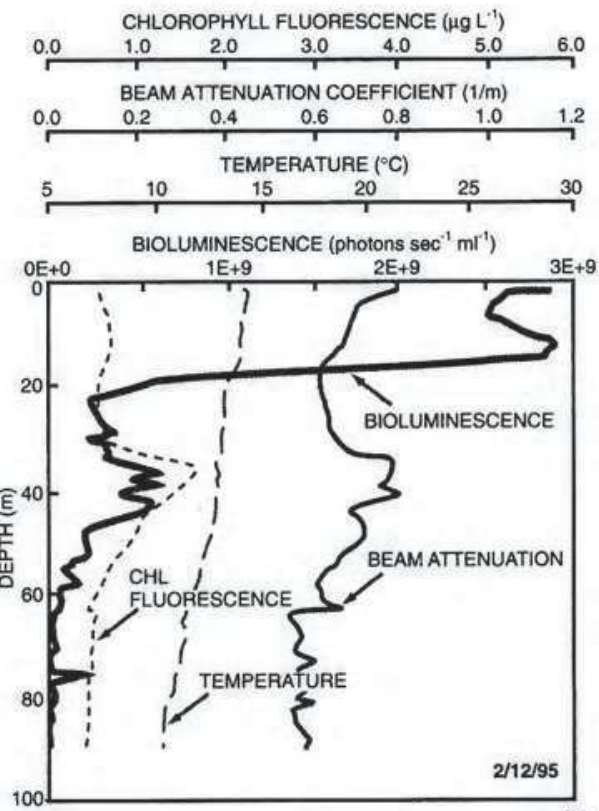

(c)

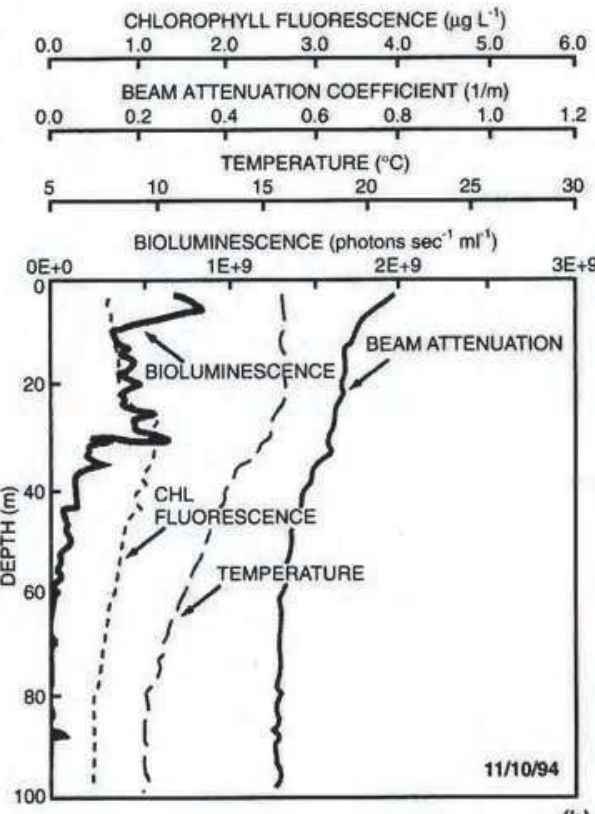

(b)
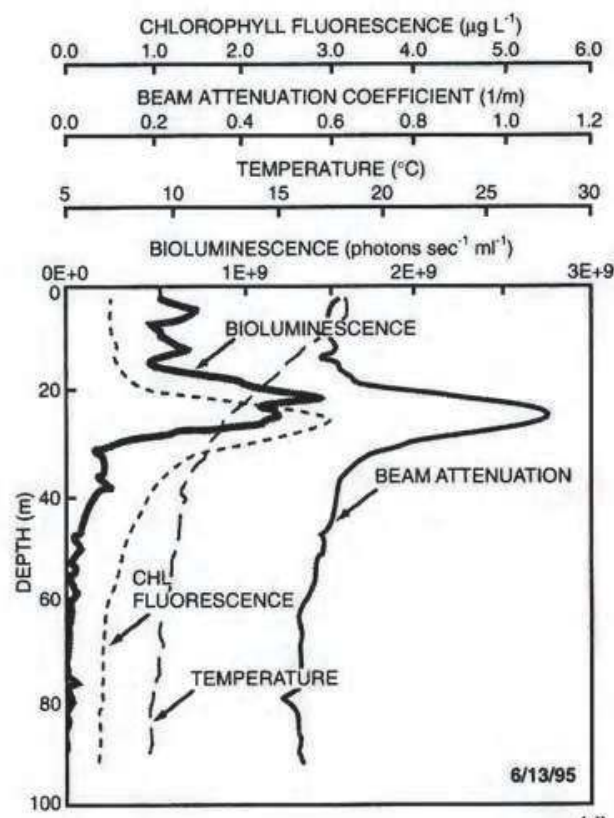

(d)

Fig. 21. Bathyphotometer profiles at station 3 for (a) July 12, 1994; (b) station 3 November 10, 1994; (c) station 3 February 12, 1995; (d) station 3 June 13, 1995. 
found at SCI. Protoperidinium spp. and Gonyaulax polyedra contributed most of the bioluminescence at both sites. Noctiluca miliaris contributed substantial bioluminescence following increases in G. polyedra at SDB in 1995 and 1996 and at SCI in 1995.

Total rainfall was significantly correlated with measured bioluminescence at SDB $(r=0.908$; $\mathrm{n}=4 ; \mathrm{p}<0.05)$. Years with the greatest rainfall $(1993,1995)$ affected the total bioluminescence which implies that processes associated with rainfall, such as storm water runoff may be stimulating dinoflagellate and algal production in coastal waters (Anderson 1964; Eppley et al., 1978). We observed that the upwelling index did not directly correlate with SDB bioluminescence unless the index was shifted back 1 month $(r=0.476 ; p<0.001)$. However, if mean monthly bioluminescence was shifted forward 2 months with mean rainfall, a significant correlation was observed $(\mathrm{r}=0.472 ; \mathrm{p}<0.01)$. The upwelling index and nitrates $\left(\mu \mathrm{m} \mathrm{L}^{-1}\right)$ measured in coastal waters, were significantly correlated when nitrate levels were shifted forward in time 1 month $(\mathrm{r}=0.679 ; \mathrm{p}<0.001)$. We must then assume that some other factor besides upwelling is providing a stimulatory effect to dinoflagellate bioluminescence. Multiple regression analysis showed that rainfall, upwelling, and temperature were the most important conditions to predict bioluminescence and that when rainfall was moved ahead in time by 2 months, we could account for $24.7 \%$ of the observed variance to predict bioluminescence from $1992-1996\left(\mathrm{R}^{2}=0.2468 ; \mathrm{F}=2.469 ; \mathrm{p}<0.05\right)$. Increased nitrate levels were observed in coastal waters beyond SCI during the winter months and spring months; before maximum upwelling. The source of these nitrates may be in storm water runoff. Support for "new sources of nitrogen" versus "recycled nitrogen" and other nutrients entering the water column is not new. Some studies have shown that river inputs into the ocean can carry high levels of nutrients needed for algal growth (Harrison 1980, Fogg 1982, Mooers et al. 1978, Lalli and Parsons, 1993). Others have found that ferric iron is a limiting nutrient for phytoplankton growth (Menzel and Ryther 1961) and that high levels of iron are often associated with river runoff (Williams and Chan 1966). Iron is needed by phytoplankton to utilize nitrates for growth (Ryther and Kramer 1961). The availability of iron is enhanced by chelation with dissolved organic matter. That is, organically bound iron from storm runoff may stimulate the growth of phytoplankton (Kawaguchi and Lewitus 1996). Similarly, elevated phytoplankton levels off Del Mar, California following storm water runoff were attributed to increased nutrient inputs from land (Eppley et al. 1978).

The bathyphotometer stations showed that bioluminescence and Chl fluorescence were positively correlated, during the summer months, when the water column stabilized with a shallow thermocline. These significant positive correlations broke down with water column mixing during the fall and winter months but were reestablished with the development of the thermocline during the spring and summer months. Several species of Protoperidinium were the predominant dinoflagellate in the spring and summer months while G. polyedra was important during the fall and winter months; not only in surface waters, but at depth. The increased bioluminescence and chlorophyll levels associated with the red tide at SCI are remarkable for their duration since they persisted from January through April 1995. This strengthens the inference that the physical environment in the bight is fairly stable with respect to seasonality, and that bioluminescence is strongly influenced by seasonal rainfall and runoff. 
Southern California Bight bioluminescence is similar to that found in coastal waters of Vestfjord, Norway (Lapota 1990, unpublished), and the Arabian Sea (Lapota \& Rosenberger 1990), but higher than that found in the Sargasso Sea (Batchelder \& Swift 1989), the North Atlantic (Neilson et al. 1995) and the Beaufort Sea (Lapota et al. 1992). The vertical structure of bioluminescence was correlated with Chl fluorescence for some of the stations in the Bight. However, integrations between bioluminescence and chlorophyll were positively correlated, but weak. Strong positive correlations between bioluminescence and chlorophyll fluorescence were observed during the red tide in February 1995. At depth, seawater temperature correlated strongly with the vertical distribution of bioluminescence, as did transmission. In contrast, weaker correlations were observed between bioluminescence and Chl fluorescence. Other studies have infrequently observed correlations which may be dependent on the season the study was conducted (Lapota et al. 1989 Young et al. 1992, Neilson et al. 1995, Ondercin et al. 1995). An obvious conclusion is that the primary dinoflagellates which are contributing much of the bioluminescence do not contain Chl $a$. These would include the heterotrophic Protoperidinium dinoflagellates. These dinoflagellates produce as much as 30 times more light per cell than does G. polyedra (Biggley 1969, Lapota et al. 1992). This could explain the poor correlations between bioluminescence and chlorophyll. Consequently, these results impact models predicting bioluminescence from global ocean primary production and ocean color (Young et al. 1992, Ondercin 1995) since these are based on the assumption that much of the oceanic bioluminescence is derived from photosynthetic bioluminescent dinoflagellates (Ondercin 1995). It is clear that from this and other studies (Lapota et al. 1989, 1992,1993 a, b, Swift et al. 1995, Neilson et al. 1995 ) that Protoperidinium dinoflagellates dominate surface water bioluminescence in the world's oceans for a significant portion of the year.

\section{Acknowledgements}

We gratefully acknowledge support by the Office of Naval Research, VA through program element 0601153N-03102 and the Naval Space and Warfare Systems Center, Pacific, CA and Dr. James Case at the University of California, Santa Barbara for his guidance throughout this study. We also thank Connie H. Liu and Joel Guerrero (Naval Space and Warfare Center, Pacific for conducting chlorophyll and chemical analyses and participation in the cruises.

\section{References}

American Public Health Association (1981). Standard methods for the examination of water and wastewater, 15th ed. Washington, D.C., 1134 pp.

Anderson, G.C.(1964). The seasonal and geographic distribution of primary productivity off the Washington and Oregon Coasts. Limnol. Oceanogr. 9: 284-302.

Armstrong, F.A.J., Stearns, C.R., Strickland, J.D.H. (1967) The measurement of upwelling and subsequent biological processes by means of the Technion Autoanalyser ${ }^{\circledR}$ and associated equipment. Deep-Sea Res.14: 381-389.

Bakun, A. (1973). Coastal upwelling indices, west coast of North America, 1946-71, Nat. Oceanic Atmos. Adm. (US), Spec. Sci. Rep.- Fish No. 671, 103 pp.

Batchelder, H.P., Swift, E. (1989). Estimated near-surface mesoplanktonic bioluminescence in the western North Atlantic during July 1986. Limnol. Oceanogr. 34: 113-128. 
Biggley, W.H., Swift, E., Buchanan, R.J., Seliger, H.H. (1969). Stimulable and spontaneous bioluminescence in the marine dinoflagellates, Pyrodinium bahamense, Gonyaulax polyedra, and Pyrocystis lunula. J. Gen. Physiol. 54: 96-122.

Bityukov, E.P., Rybasov, V.P., Shaida, V.G. (1967). Annual variations of the bioluminescent field intensity in the neritic zone of the Black Sea. Oceanology 7 (6): 848-856.

Case, J.F., Widder, E.A., Bernstein, S., Ferer, K., Young, D., Latz M., Geiger, M., Lapota, D. 1993). Assessment of marine bioluminescence. Nav. Res. Rev. 45: 31-41.

Clarke, G.L., Kelly, M.G. (1965). Measurements of diurnal changes in bioluminescence from the sea surface to 2,000 meters using a new photometric device. Limnol. Oceanogr. 10 (supplement), R54-66.

Dugdale, R.C. (1967). Nutrient limitation in the sea: dynamics, identification and significance. Limnol. Oceanogr. 12: 685-695.

Eppley, R.W., Sapienza, C., Renger, E.H. (1978). Gradients in phytoplankton stocks and nutrients off southern California in 1974-76, Estuarine Coastal Mar. Sci. 7: 291-301.

Eppley, R.W. (1986). Plankton Dynamics of the Southern California Bight, Lecture Notes on Coastal and Estuarine Studies, XIII. Eppley, R.W.(ed.), Springer-Verlag, Berlin, 373 pp.

Fogg, G.E. (1982). Nitrogen cycling in sea waters. Phil. Trans. Roy. Soc. Lond. Ser. B, 296: 511-520.

Harrison, W.G. (1980). Nutrient regeneration and primary production in the sea. In: Falkowski, P. (ed.) Primary Productivity in the Sea, Brookhaven Symposium Biology 31, Plenum, New York, pp. 433-460.

Hayward, T.L., Cummings, S.L., Cayan, D.R., Chavez, F.P., Lynn, R.J., Mantyla, A.W., Niiler, P.P., Schwing, F.B., Veit, R.R., Venrick, E.L. (1996). The state of the California Current in 1995: Continuing declines in macrozooplankton biomass during a period of nearly normal circulation. CalCOFI Reports 37: 22-37.

Holm-Hansen, O., Strickland, J.D.H., Williams, P.M. (1966). A detailed analysis of biologically important substances in a profile off southern California. Limnol. Oceanogr. 11: 548-561.

Kawaguchi, T., Lewitus, A.J. (1996). The potential effect of urbanization on iron Bioavailability and the implication for phytoplankton production, International Conference on Shellfish Restoration, South Carolina Sea Grant, Hilton Head, South Carolina, USA, 20-23 November 1996.

Kinnetic Laboratories, Inc (1995). City of San Diego and Co-Permittee Stormwater Monitoring Program 1994-1995, Carlsbad, Calif.

Lalli, C.M., Parsons, T.R. (1993). Biological Oceanography, Pergamon Press, Oxford, England, pp. 141-143.

Lapota, D., Losee, J.R. (1984). Observations of bioluminescence in marine plankton from the Sea of Cortez. J. exp. Mar. Biol. Ecol. 77: 209-240.

Lapota, D., Galt, C., Losee, J.R., Huddell, H.D., Orzech, K., Nealson, K.H. (1988). Observations and measurements of planktonic bioluminescence in and around a milky sea. J. exp. Mar. Biol. Ecol. 119: 55-81.

Lapota, D., Geiger, M.L., Stiffey, A.V., Rosenberger, D.E., Young, D.K. (1989). Correlations of planktonic bioluminescence with other oceanographic parameters from a Norwegian fjord. Mar. Ecol. Prog. Ser. 55: 217-227.

Lapota, D., Rosenberger, D.E. (1990). Bioluminescence measurements and light budget analysis in the western Arabian Sea. EOS, Trans. of the Am. Geophy. Union 71: 97.

Lapota, D., Rosenberger, D.E., Lieberman, S.H. (1992a). Planktonic bioluminescence in the pack ice and the marginal ice zone of the Beaufort Sea. Mar. Biol. 112:665-675. 
Lapota, D., Young, D.K., Benstein, S.A., Geiger, M.L., Huddell, H.D., Case, J.F. (1992b). Diel bioluminescence in heterotrophic and photosynthetic marine dinoflagellates in an Arctic Fjord. J. mar. biol. Ass. U.K. 72: 733-744.

MacIsaac, J.J., Dugdale, R.C. (1967). The kinetics of nitrate and ammonia uptake by natural populations of marine phytoplankton. Deep-Sea Res. 16: 45-57.

Matheson, I.B.C., Lee, J., Zalewski, E.F. (1984). A calibration technique for photometers. Ocean Optics 7 (489): 380-381.

Menzel, D.W., Ryther, J.H. (1961). Nutrients limiting the production of phytoplankton in the Sargasso Sea, with special reference to iron. Deep-Sea Res. 7: 276-281.

Mooers, C.N.K., Flagg, C.N., Boicourt, W.C. (1978). Prograde and retrograde fronts. In Bowman, M., Esias, W.E. (eds.) Ocean Fronts in Coastal Processes, Springer, Berlin, pp. 43-58.

Neilson, D.J., Latz, M.I., Case, J.F. (1995). Temporal variability in the vertical structure of bioluminescence in the North Atlantic ocean. J. Geophys. Res. 100 (C4):6591-6603.

Ondercin, D.G., Atkinson, C.A., Kiefer, D.A. (1995). The distribution of bioluminescence and chlorophyll during the late summer in the North Atlantic: Maps and a predictive model. J. Geophys. Res. 100 (C4): 6575-6590.

Ryther, J.H., Kramer, D.D. (1961). Relative iron requirement of some coastal and off-shore plankton algae. Ecology 42: 444-446.

Schwing, F.B., O'Farrell, M., Steger, J., Baltz, K. (1996). Coastal upwelling indices, west coast of North America 1946-1995. NOAA-TM-NMFS-SWFSC-231.

Seliger, H.H., Fastie, W.G., Taylor, W.R., McElroy, W.D. (1961). Bioluminescence in Chesapeake Bay. Science 133: 699-700.

Spencer, C.P. (1954). Studies on the culture of a marine diatom. J. mar. biol. Ass. U.K. 33: 265-290.

Strickland, J.D.H. (1968). A comparison of profiles of nutrient and chlorophyll concentrations taken from discrete depths and by continuous recording. Limnol. Oceanogr. 13: 388-391.

Stukalin, M.V. (1934) Bioluminescence of the Okhotsk Sea. Vest dal'nevost Fil. Akad. Nauk. SSSR 9: 137-139.

Swift, E., Sullivan, J.M., Batchelder, H.P., Van Keuren, J., Vaillancourt, R.D. (1995). Bioluminescent organisms and bioluminescent measurements in the North Atlantic Ocean near latitude $59.5^{\circ} \mathrm{N}$, longitude $21^{\circ} \mathrm{W}$. J. Geophy. Res. 100 (C4):6527-6547.

Tarasov, N.I. (1956). Marine luminescence. USSR Academy of Sciences, Moscow [in Russ.] [Engl transl by Naval Oceanographic Office (No NOOT-21); National Space Technology Laboratories Station, Bay St. Louis, MS].

Tett, P.B. (1971). The relation between dinoflagellates and the bioluminescence of sea water. J. mar. biol. Ass. U.K. 51:183-206.

Williams, P.M., Chan, K.S. (1966). Distribution and speciation of iron in natural waters: Transition from river water to a marine environment, British Columbia, Canada. J. Fish. Res. Bd. Canada 23: 575-593.

Yentsch, C.S., Laird, J.C. (1968). Seasonal sequence of bioluminescence and the occurrence of endogenous rhythms in oceanic waters off Woods Hole, Massachusetts. J. mar. Res. 26:127-133.

Young, D.K., Lapota, D., Hickman, G.D. (1992). Ocean color effects on the operation of active and passive optical aircraft/satellite systems, Applications of ocean color to Naval warfare, In: Hickman, G.D. (ed.) Applications of Ocean Color to Naval Warfare. Naval Oceanographic and Atmospheric Research Laboratory, Stennis Space center, MS 39529-5004, pp 32-43. 


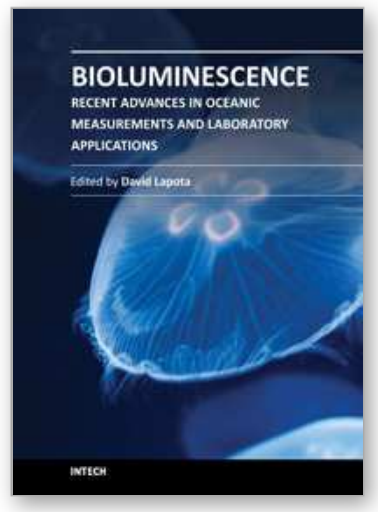

\section{Bioluminescence - Recent Advances in Oceanic Measurements and Laboratory Applications}

Edited by Dr. David Lapota

ISBN 978-953-307-940-0

Hard cover, 190 pages

Publisher InTech

Published online 01, February, 2012

Published in print edition February, 2012

We now find ourselves utilizing luciferase - luciferin proteins, ATP, genes and the whole complex of these interactions to observe and follow the progress or inhibition of tumors in animal models by measuring bioluminescence intensity, spatially and temporally using highly sophisticated camera systems. This book describes applications in preclinical oncology research by bioluminescence imaging (BLI) with a variety of applications. Chapters describe current methodologies for rapid detection of contaminants using the Milliflex system, and the use of bioluminescence resonance energy transfer (BRET) technology for monitoring physical interactions between proteins in living cells. Others are using bioluminescent proteins for high sensitive optical reporters imaging in living animals, developing $\mathrm{pH}$-tolerant luciferase for brighter in vivo imaging, and oscillation characteristics in bacterial bioluminescence. The book also contains descriptions of the long-term seasonal characteristics of oceanic bioluminescence and the responsible planktonic species producing bioluminescence. Such studies are few and rare.

\section{How to reference}

In order to correctly reference this scholarly work, feel free to copy and paste the following:

David Lapota (2012). Long Term Dinoflagellate Bioluminescence, Chlorophyll, and Their Environmental Correlates in Southern California Coastal Waters, Bioluminescence - Recent Advances in Oceanic Measurements and Laboratory Applications, Dr. David Lapota (Ed.), ISBN: 978-953-307-940-0, InTech, Available from: http://www.intechopen.com/books/bioluminescence-recent-advances-in-oceanicmeasurements-and-laboratory-applications/long-term-dinoflagellate-bioluminescence-chlorophyll-and-theirenvironmental-correlates-in-southern-

\section{INTECH}

open science / open minds

\section{InTech Europe}

University Campus STeP Ri

Slavka Krautzeka 83/A

51000 Rijeka, Croatia

Phone: +385 (51) 770447

Fax: +385 (51) 686166

www.intechopen.com

\section{InTech China}

Unit 405, Office Block, Hotel Equatorial Shanghai

No.65, Yan An Road (West), Shanghai, 200040, China 中国上海市延安西路65号上海国际贵都大饭店办公楼 405 单元

Phone: +86-21-62489820

Fax: $+86-21-62489821$ 
(C) 2012 The Author(s). Licensee IntechOpen. This is an open access article distributed under the terms of the Creative Commons Attribution 3.0 License, which permits unrestricted use, distribution, and reproduction in any medium, provided the original work is properly cited. 